\title{
Sedimentary environment evolution in a marine hangingwall dipslope setting. El Qaa Fault Block, Suez Rift, Egypt \\ DOI:
}

10.1111/bre.12231

\section{Document Version}

Accepted author manuscript

Link to publication record in Manchester Research Explorer

Citation for published version (APA):

Muravchik, M., Gawthorpe, R., Sharp, I. R., Rarity, G., \& Hodgetts, D. (2017). Sedimentary environment evolution in a marine hangingwall dipslope setting. El Qaa Fault Block, Suez Rift, Egypt. Basin Research.

https://doi.org/10.1111/bre.12231

\section{Published in:}

Basin Research

\section{Citing this paper}

Please note that where the full-text provided on Manchester Research Explorer is the Author Accepted Manuscript or Proof version this may differ from the final Published version. If citing, it is advised that you check and use the publisher's definitive version.

\section{General rights}

Copyright and moral rights for the publications made accessible in the Research Explorer are retained by the authors and/or other copyright owners and it is a condition of accessing publications that users recognise and abide by the legal requirements associated with these rights.

\section{Takedown policy}

If you believe that this document breaches copyright please refer to the University of Manchester's Takedown Procedures [http://man.ac.uk/04Y6Bo] or contact uml.scholarlycommunications@manchester.ac.uk providing relevant details, so we can investigate your claim.

\section{OPEN ACCESS}


Received Date : 14-Jul-2016

Revised Date : 03-Nov-2016

Accepted Date : 23-Dec-2016

Article type : Original Article

\section{Sedimentary environment evolution in a marine hangingwall dipslope setting. El Qaa Fault Block, Suez Rift, Egypt}

Martin Muravchik ${ }^{1}$, Rob L. Gawthorpe ${ }^{1}$, lan R. Sharp ${ }^{2}$, Franklin Rarity ${ }^{3}$, David Hodgetts ${ }^{4}$

1- Department of Earth Science, University of Bergen, Allégaten 41, N-5007, Bergen, Norway.

2- Exploration Research, Statoil ASA, Sandsliveien 90, Bergen, Norway.

3- Australian School of Petroleum, University of Adelaide, Adelaide 5005, Australia.

4- School of Earth, Atmospheric \& Environmental Sciences, University of Manchester, Manchester, M13 9PL, UK.

Corresponding author mail id : martin.muravchik@geo.uib.no

\section{ABSTRACT}

Sedimentation in hangingwall dipslope settings is still a relatively underexplored topic in rift basin studies. A better understanding of the evolution of marine sedimentary environments in this kind of settings has to address the variations occurring both along the strike and down the dipslope. Previous work was mainly built on the analysis of subsurface data, relying on the visualization of coarse resolution (10s of $\mathrm{m}$ ) seismic sections and sparsely located borehole logs ( $\mathrm{km}$ apart). This

This article has been accepted for publication and undergone full peer review but has not been through the copyediting, typesetting, pagination and proofreading process, which may lead to differences between this version and the Version of Record. Please cite this article as doi: 10.1111/bre.12231

This article is protected by copyright. All rights reserved. 
study focuses on the sedimentology and stratal arrangement of excellent quality Miocene marine early syn-rift and rift climax successions continuously exposed for more than $20 \mathrm{~km}$ along the strike of the hangingwall dipslope in the El Qaa Fault Block, Suez Rift, Egypt. The integration of traditional sedimentary field techniques and terrestrial LIDAR scanning allowed for a detailed analysis of dip and dip direction for the different depositional units. Three different phases of tilting were identified for the hangingwall dipslope, which controlled the overall evolution of the marine sedimentary environment in the area. The tilt of the hangingwall not only determined variations in facies, thickness and grain-size of the deposits down the dipslope but also along its strike. The studied exposures in the El Qaa Fault Block dipslope constitute a unique outcrop analogue for marine sedimentation in hangingwall diplsopes.

\section{INTRODUCTION}

Clastic deposition in rift basins is strongly influenced by the dynamic growth of normal fault zones and the temporal and spatial evolution of rift basins. Recognition of these factors has led to significant advances in understanding the controls on syn-rift clastic depositional systems, from subfault-block to basin scale (e.g. Ravnås \& Steel, 1998; Gawthorpe \& Leeder, 2000; Cowie et al., 2006 and references within). However, most detailed studies to date have focused on the analysis of sedimentary systems located in the immediate hangingwall of normal faults (Fig. 1A; e.g. Gupta et al., 1999; Sharp et al., 2000; Young et al., 2002, 2003; Elliot et al., 2015). Relatively few studies have investigated the sedimentary processes occurring on hangingwall dipslopes, and those that have are most relevant to the continental realm as they are largely based on the response of alluvial and fluvial drainage to ground tilting (e.g. Leeder and Jackson, 1993; Leeder et al., 1996; Muravchik et al., 2014). Studies of hangingwall dipslopes in marine settings are rare in comparison and based on subsurface datasets (Fig. 1B, C and D; e.g. Ravnås \& Bondevik, 1997; Ravnås \& Steel, 1997; Nøttvedt et al., 2000). Although tilting of the hangingwall dipslope in a half-graben is a widely recorded phenomenon, little has been published about the magnitude of such tilting (see however, Nøttvedt et al., 2000; Leeder et al., 2005). Similarly, along-strike variations in basin physiography and syn-rift stratigraphic architecture are seldom studied in the hangingwall dipslope and most models addressing these issues are biased towards observations made on the immediate hangingwall area (Young et al., 2002, 2003; Elliot et al., 2015). Developing a better understanding of the marine deposition on hangingwall dipslope areas will allow to refine existing rift basin sedimentary models. For example, relative changes in sea level combined with the effects of tilting and uplift of the hangingwall causes the emergence or submergence of the footwall crest (Ravnås \& Steel, 1998;

This article is protected by copyright. All rights reserved. 
Gawthorpe \& Leeder, 2000; Nøttvedt et al., 2000). As a result footwall islands may develop, forming intra-rift source areas and influencing the nature of the sedimentary environments developed on the dipslope (Fig. 1A). Detailed analysis and interpretation of the evolution of such footwall islands, and of the depositional history preserved on adjacent hangingwall areas will allow to identify sedimentary distribution patterns and source and sink areas with increasing confidence and will thus have important implications for rift basin exploration.

The aim of this paper is to investigate the variations in marine sedimentary environments along and perpendicular to the hangingwall dipslope and their relation to the tilting of the hangingwall in a half-graben setting. Analysis focuses on the evolution of a Miocene rift initiation to climax succession exposed in the El Qaa Fault Block, Suez Rift, Egypt. The exceptional quality of the exposures and the lateral continuity of the outcrops for tens of kilometres along the strike of the hangingwall dipslope provide the opportunity to generate seismic-scale observations of pertinence for both surface and subsurface basin analyses.

\section{GEOLOGICAL SETTING}

The Suez Rift comprises the Gulf of Suez and its margins along the Eastern Desert and the western Sinai Peninsula, Egypt (Fig. 2). It extends for about $300 \mathrm{~km}$ in length and up to $80 \mathrm{~km}$ in width. The Suez Rift constitutes the northwest branch of the Red Sea Rift, and it developed as a result of the separation of the Arabian and African plates in the Oligo-Miocene (e.g. Robson, 1971; Garfunkel and Bartov, 1977; Patton et al., 1994; Bosworth \& McClay, 2001; Bosworth et al., 2005). The dominant rift structures strike NW-SE to NNW-SSE and are linked by subordinate NNE-SSW, E-W and N-S orientated faults. Differences in fault polarity and fault-block tilt direction allow the Suez Rift to be divided into three symmetric dip provinces (e.g. Colleta et al., 1988; Moustafa, 1993), separated by accommodation zones transverse to the rift (Patton et al., 1994; Moustafa, 1996, 1997; Bosworth et al., 2005). In the northern and southern dip provinces the dominant normal faults dip to the northeast while strata dip to the southwest. In contrast, in the central dip province the dominant normal faults dip to the southwest and strata dip to the northeast.

This study is based on field data from the El Qaa Fault Block (EQFB), exposed on the western coast of Sinai in the central dip province (Fig. 2). The EQFB is bounded by the Coastal Fault Belt to the west and by the Eastern Boundary Fault Belt to the east (Fig. 2). The Coastal Fault Belt includes the Nezzazzat, Ekma, Durba and Araba fault segments and the Eastern Boundary Fault Belt comprises the Baba-Sidri, Hadahid and Gebah fault segments (Moustafa, 1993, 2004).

This article is protected by copyright. All rights reserved. 
The Precambrian Pan-African igneous-metamorphic basement is the oldest lithology exposed on the eastern margin of the Suez Rift and is overlain by three sedimentary pre-rift sections: a Cambrian to Early Creatceous sandstone section (Nubia Sandstone), an Early Cretaceous mixed siliciclastic and carbonate section and a Maastrichtian to Late Eocene carbonate section (Fig. 3). The syn-rift succession in the EQFB comprises the marine Miocene Gharandal and Ras Mallab groups (Fig. 3). The post-rift units in the study area are composed of Quaternary eolian, alluvial and colluvial deposits (Fig. 3).

\section{DIPSLOPE SETTING}

The present configuration of the EQFB consists of a broad synclinal structure running parallel to the half-graben border faults (Fig. 2). During the growth of this half-graben the eastern margin was the active margin, while the western margin was the passive one (e.g. Robson, 1971; Garfunkel \& Bartov, 1977; Gupta et al., 1999; Sharp et al., 2000). The EQFB dipslope is now exposed for tens of kilometres along the strike of the western limb of the El Qaa syncline (Figs 2 and 4), dipping gently to the east-northeast and bounded to the west by the present-day footwall crest of the Coastal Fault Belt. In the study area the EQFB dipslope corresponds approximately to the Nezzazzat Block (cf. Moustafa, 2004).

The topography of the study area during the initial rifting in the Gulf of Suez is interpreted to have been at or near sea level (Bosworth \& McClay, 2001; Bosworth et al., 2005), with no evidence for crustal doming or uplift prior to rifting (Garfunkel \& Bartov, 1977; Moustafa, 1993, 2004). The sedimentary pre-rift and syn-rift units that make up the displope of the EQFB dip to the east (Figs 4 and 5), and differences in dip between the pre-rift and syn-rift sequences and also within the syn-rift indicate eastward tilting of the hangingwall during rifting (Fig. 6). The boundary between the pre-rift and syn-rift sequences is defined by an angular unconformity of $\sim 40$ (Fig. 6). This erosional surface progressively truncates the Eocene pre-rift Thebes, Darat and Mokattam formations in a westward direction, towards the present-day crest of the Coastal Fault Belt (Fig. 7). The syn-rift stratigraphy in the dipslope area has been divided in this study into seven units according to their main sedimentary characteristics (Fig. 6). Correlation between these units and those defined in previous regional lithostratigraphic (Moustafa, 2004) and biostratigraphic (Wescott et al., 1996; Krebs et al., 1997) studies in the area is shown in Fig. 6 . This study focuses on clastic sedimentation during the early syn-rift to rift climax stages, comprising Units 1 through to 4 (Fig. 6). The younger units on the dipslope (Units 5 through to 7; Fig. 6) correspond to a stage when the tectonic subsidence

This article is protected by copyright. All rights reserved. 
diminished, but other factors such as sea water circulation and climate became more significant and will be the subject of future research.

\section{METHODOLOGY}

This study is based on detailed geological mapping (at 1:5500 scale) and logging (at 1:10 scale) of sedimentary and stratigraphic sections along the strike of the EQFB hangingwall dipslope (Fig. 4). Twenty sedimentological sections were logged from which facies and depositional units were defined and analysed in order to characterise the main sedimentary systems on the dipslope. Structural and sedimentary orientation data were systematically measured in the field using a compass-clinometer and from a LIDAR (Light Detection and Ranging) surveyed dataset. Sedimentary and structural data were combined with cross sections (Fig. 5) and correlation panels (Figs 10, 11 and 12 ) on the dipslope in order to obtain a 3D understanding of the sedimentary environments.

Measurements of the dip and dip direction of bedding and bounding surfaces in the upper pre-rift (i.e. Thebes and Darat formations) and the syn-rift units were analysed in order to quantify tilting of the hangingwall block during different phases of rifting. Due to the regional character of the surfaces, which can extend for several kilometres along strike, methods comprising larger measuring areas were preferred (i.e. larger than the $\sim 50 \mathrm{~cm}^{2}$ of an average compass-clinometer) in order to remove local irregularities in orientation due to small-scale erosion or depositional geometry. Analysis focused mainly on the examination of a LIDAR surveyed dataset of approximately $8 \mathrm{~km}^{2}$ of the dipslope (Fig. 4) that includes almost all the stratigraphic units in the dipslope, from the pre-rift up to and including Unit 6 (Fig. 8). The geological interpretation of the LIDAR data was done in Virtual Reality Geological Studio software (VRGS, e.g. Hodgetts, 2009; Rarity et al., 2014), obtaining measurements that cover areas of influence that range from few meters to hundreds of meters (Fig. 8). Measurements from Unit 7 were obtained with a laser range finder (Fig. 8).

\section{DIPSLOPE ANGULAR UNCONFORMITIES}

Analysis of the attitude of the bedding and bounding surfaces in the dipslope units shows clear differences in dip and dip direction through the stratigraphy (Figs 6 and 8). The dip direction changes from ENE in the pre-rift and syn-rift Unit 1 to $E$ in the overlying syn-rift units, and an overall upsection decrease in dip is observed that can be divided into at least three tilt phases directed towards ENE and E (Figs 6 and 8). The first phase corresponds to the $\sim 40$ difference in dip between

This article is protected by copyright. All rights reserved. 
the pre-rift and syn-rift strata (average dip $15.103^{\circ}$ and $10.707^{\circ}$ respectively; Fig. 8) and is represented by the angular unconformity marking the pre-rift/syn-rift boundary. Although the tilt direction of this first phase is clearly directed towards the ENE (Fig. 8B) causing the progressive truncation of the pre-rift units towards the west (Figs 5A, 5B, 5C, 5D, 7A and 7B), the pre-rift/syn-rift boundary also erodes into progressively older horizons from SSE to NNW along the displope strike (Fig. 9). The differences in dip of the pre-rift units observed along strike the dipslope (Fig. 9B) are very small, but occur over a large distance and are enough to account for the erosion of the whole of the Darat Fm from SSE to NNW. These differences in dip can result from small variations in the tilting of the hangingwall block along strike the Coastal Fault Belt during vertical fault propagation folding and the lateral propagation of the fault segments. The development of one steeper segment in this surface boundary in the area of Wadi Feiran (Fig. 9B) indicates the existence of local variations in the topography during the early-rift marine transgression. Syn-rift Unit 1 is conformable with this surface, but there is a difference in dip of $\sim 3.5^{\circ}$ between Unit 1 (average dip $11.143^{\circ} ;$ Fig. 8) and Unit 3 (average dip $7.512^{\circ}$; Fig. 8). There is an angular unconformity at the base of Unit 2, but the erodible nature of Unit 2 (mudstone-dominated) makes it hard to determine whether this unconformity accounts for the entire interval difference of $\sim 3.5 \%$. Other angular unconformities may lie undetected within Unit 2. The basal surface underlying units 3 and 4 is conspicuously erosive, but no dip difference was detected between the top of Unit 2 and lowermost beds in units 3 and 4 . Therefore the second phase of tilting is interpreted to be represented by the entire interval corresponding to Unit 2. There is less than 10 difference in dip between units 3 and 4 and the youngest preserved syn-rift unit in the area (the Unit 7 topset), and this difference is small enough that it could be an error inherent in the measuring method. For the purposes of this study the strata from units 3 and 4 through 7 are interpreted as one conformable succession. The third phase of tilting is thus represented by the 70 dip of the topset of Unit 7.

The measured angular relationships described above are indicative of tilting phases produced in ENE to E directions. This is consistent with the tilt directions expected for the EQFB hangingwall given the NW-SE orientation of its bounding structures. Consequently, surface tilting produced by hangingwall block tilting is likely to be the primary control behind the development of these depositional units in the dipslope. It is extremely difficult to state precisely whether each of these three tilt phases represents a single pulse of tilting in the hangingwall or if they resulted from multiple superposed episodes clustered in time. This is especially the case for the last phase, in which not much stratigraphy is preserved above Unit 7 that could help to constrain this matter. It is important to note however, the great similarity in the angular magnitude of the first two phases.

This article is protected by copyright. All rights reserved. 


\section{DIPSLOPE DEPOSITIONAL UNITS}

This section describes the four units that form the early syn-rift and rift climax in the El Qaa hangingwall dipslope, the stratigraphic relations between them along strike and down the dipslope (Figs 10, 11 and 12) and the ten sedimentary facies that compose them (Fig. 13). Age constraints for the sedimentary units in the dipslope are limited. Biostratigraphic data logged in close proximity to Log 2 (Fig. 10) on the southern margin of Wadi Feiran show that units 3 and 4 are approximately of N7-N8 age, equivalent to Burdigalian and Langhian in the Miocene (Fig. 6; Wescott et al., 1996; Krebs et al., 1997). The surface at the base of units 3 and 4 has been correlated (Wescott et al., 1996; Krebs et al., 1997) with a regional sequence boundary (T20) which is known as the MidClysmic Event and is widely interpreted to have had a basin-scale tectonic origin (e.g. Garfunkel \& Bartov, 1977; Patton et al., 1994; Bosworth \& McClay, 2001). Wescott et al. (1996) and Krebs et al. (1997) also based on the biostratigraphic data obtained close to Log 2 (Fig. 10) interpreted the unconformity between units 3 and 4 on the one side and Unit 1 below to represent all the time from their T00 to T20 (i.e. N4 to N7, from Aquitanian to Burdigalian in the Miocene, from the earliest synrift until the Mid-Clysmic Event).

\section{Unit 1 (monolithologic conglomerates and bioclastic rudstones)}

Unit 1 is bounded below by the pre-rift/syn-rift contact and above by Units 2, 3 and 4 . North of Wadi Feiran, the unit has a tabular geometry and varies in thickness from 5 to $8 \mathrm{~m}$ for $\sim 10 \mathrm{~km}$. South of this locality it shows a gradual thickening towards the SSE, reaching up to $20 \mathrm{~m}$ at Log 1 (Fig. 10). The pre-rift/syn-rift contact shows steplike erosion features that alternately parallel and steeply truncate the underlying pre-rift strata on a wavelength of a few metres (Fig. 14A). In addition, abundant borings of Gastrochaenolites isp., Trypanites isp. and Entobia isp. extend downwards from the contact for up to $10 \mathrm{~cm}$ (Fig. 14B). Facies distribution within Unit 1 is characteristically homogenous and monotonous, onlapping straight onto the pre-rift units and extending almost invariably for more than $16 \mathrm{~km}$ along strike the dipslope. The oldest syn-rift deposits found in the area are discontinuous lenses of conglomerate (Facies $1 \mathrm{~A}$ ) comprising clasts and matrix of the same composition as the immediately underlying pre-rift unit (i.e. Matulla, Darat or Mokattam Formations). The conglomerates are overlain by bioclastic rudstones (Facies 1B) that are continuously exposed along the dipslope, lying directly on top of the pre-rift where the basal conglomerates are absent (Fig. 10).

This article is protected by copyright. All rights reserved. 


\section{Facies $1 A$ (monolithologic conglomerates)}

Facies 1A comprises flat-topped, erosive-based lenses of poorly sorted, grain-supported pebble grade conglomerate (Fig. 13A). Long axes of the erosional bases are orientated NE-SW, transverse to the strike of the dipslope. The lenses are a few centimetres to $5 \mathrm{~m}$ thick and extend along strike for up to $3 \mathrm{~km}$. Depending on the underlying pre-rift unit the clasts are composed exclusively as follows: i) loose nummulites and nummulitic rock fragments on deposits overlying the Mokattam Formation, ii) chalk clasts on deposits overlying the Darat Formation, and iii) chalk and chert clasts on deposits overlying the Thebes Formation (e.g. Fig. 14C). The conglomerates contain oblate, angular to subangular clasts which mean size ranges from 1 to $8 \mathrm{~cm}$, and maximum size ranges from 40 to $50 \mathrm{~cm}$. Abundant disarticulated marine shells are found scattered throughout the deposit.

Facies 1B (bioclastic rudstones)

Unit 1 is dominated by bioclastic rudstones, which occur as extensive tabular beds with planar irregular bases and tops (Figs 13A, 14D and 14E). Beds are commonly massive, but appear crudely stratified where platy shells are aligned. The grain size largely depends on the type of bioclasts and is most commonly between 1 and $10 \mathrm{~cm}$, but up to $20-30 \mathrm{~cm}$ in the case of the biggest oysters. The matrix is composed of variable proportions of coarse to very coarse sand and broken bioclasts up to $4 \mathrm{~mm}$. Although the degree of abrasion and breakage of the bioclastic material is variable, the state of preservation of the bioclasts is generally very good and distinctive horizons a few centimetres thick with whole, articulated bivalves are commonly preserved. The most common bioclasts identified are: pectinids, oysters, regular and irregular echinoid bodies and spines, gastropods, balanids, coral fragments, brachiopods, shark teeth and encrusting serpulids and bryozoans. Floating pebbles and cobbles of carbonate and chert derived from the underlying pre-rift strata are also found.

Rare tabular conglomerate beds 0.5 to $5 \mathrm{~m}$ thick containing a higher proportion of terrigenous material than bioclasts are also found intercalated with the type of deposits described above (Fig. 13A). In this more mixed variant, the terrigenous component tends to be dominant in the grain fraction, with bioclastic material concentrated in the matrix. Mean clast size of the terrigenous components ranges from 1 to $5 \mathrm{~cm}$.

This article is protected by copyright. All rights reserved. 


\section{Interpretation}

The trace fossil assemblage at the pre-rift/syn-rift contact is typical of marine boring into a fully lithified substrate with little or no contemporaneous sedimentation (e.g. MacEachern et al., 2007), and the development of Facies $1 \mathrm{~A}$ as very thin, but laterally extensive lenses on top of a major angular unconformity is also consistent with an environment initially dominated by erosion over deposition. Compositional similarities between the conglomerate clasts and the underlying pre-rift unit indicate short transport distances and local erosion and deposition. The coarse-grained nature of the facies and the bioclastic composition of Facies 1B provide evidence of high energy, open marine conditions with normal salinity and well oxygenated water. The very low proportion of terrigenous material in Unit 1 points to starved sedimentation or bypassing and/or lack of terrigenous sources.

The pervasive borings found at the pre-rift/syn-rift contact indicate that marine conditions were already established in the area by the time the basal surface was formed. Marine erosion is therefore interpreted as the main agent leading to truncation of the pre-rift substrate, and Unit 1 as a whole is interpreted to represent the marine transgression that led to deposition of the syn-rift succession. Facies $1 \mathrm{~A}$ corresponds to the initial flooding stage that reworked the pre-rift top, leaving behind a transgressive surface and a discontinuous lag that was subsequently covered by Facies $1 \mathrm{~B}$ shell beds. The NE-SW orientation of the conglomerate lenses reflects the orientation of the initial marine transgression. Shell beds are often associated with transgressive surfaces as condensed deposits formed during a transgression (e.g. Kidwell, 1991; Cattaneo \& Steel, 2003). Their basal position in the syn-rift marine megasequence and their onlap onto the pre-rift substrate allow for interpreting Facies 1B as a case of condensed onlap (cf. Kidwell, 1991). Thickening of Facies 1B towards the SSE indicates persistence of shallow water conditions in that same direction, while the thinning north of Wadi Feiran points to a deeper water environment.

\section{Unit 2 (mudstone-dominated)}

Unit 2 comprises a distinctive wedge that thickens both along strike (towards the NNW; Figs 5E and 10) and down the dipslope (towards the ENE; Figs 5A, 5B, 5C, 7A and 12). It overlies Unit 1 north of Wadi Feiran, while it pinches out below Unit 3 (see below) around the Wadi Feiran area (Figs 4 and 10). Unit 2 is composed almost entirely of mudstones.

This article is protected by copyright. All rights reserved. 
Facies 2 B (fine-grained deposits)

Monotonous successions, up to 125 m thick, of green finely laminated mudstones characterise this unit (Fig. 13B). Beds are tabular, with sharp bases and tops, and range from 0.5 to $5 \mathrm{~cm}$ thick (Fig. 15). Bioturbation ranges from low to intense and includes burrows formed by both suspension and deposit feeders, including Chondrites isp., Planolites isp. and Skolithos isp. Bioclasts and pre-rift derived lithoclasts 0.2 to $3 \mathrm{~cm}$ in size can be found locally, either floating in the mudstones or as discontinuous lenses one clast thick. Intercalations of 1 to $5 \mathrm{~cm}$ thick tabular siltstone and well sorted very fine to medium sandstone beds with sharp, planar bases and tops also occur. The siltstones are laminated, while the sandstones may be laminated, cross-laminated or, less frequently, massive.

\section{Interpretation}

Unit 2 represents predominantly low energy conditions, dominated by settling from suspension, but with intermittent increases in the environmental energy indicated by the siltstone and sandstone intercalations. The presence of cross-lamination in the sandstones, together with their well sorted nature, suggests deposition from traction currents. The development of locally intense bioturbation is indicative of a well oxygenated sea floor with abundant nutrients (e.g. Gowland, 1996, MacEachern et al., 2007). The depositional environment is interpreted as a proximal offshore generally below storm wave base, but with influence of occasional near-bottom traction currents (e.g. Gowland, 1996; Clifton, 2006).

\section{Unit 3 (conglomerate-dominated)}

This prominent conglomerate-rich succession is exposed in both margins of Wadi Feiran, overlying Unit 2 over a planar sharp erosive basal surface towards the north and directly onlapping Unit 1 towards the south (Figs 4 and 10). The unit mainly comprises 10 to $30 \mathrm{~m}$ thick successions of conglomerates (Facies 3A) and sandstone beds (Facies 3C) (Figs 10 and 12). Down dip from WSW to ENE, the conglomerates and sandstones exposed on the northern margin of Wadi Feiran expand and intercalate with Unit 4 siltstones and mudstones (Facies 4D) (from Log 5 to 4; Fig. 12). South of Wadi Feiran Unit 3 thins and intercalates with Unit 4 bioturbated sandstones (Facies 4A, Logs 1 and 2; Fig. 10), but to the north its contact with Unit 4 sandy facies (Facies $4 A$ and $4 B$ ) is not exposed because of modern-day erosion (between Logs 6 and 7; Fig. 10).

This article is protected by copyright. All rights reserved. 


\section{Facies 3A (matrix-supported conglomerates)}

This is the commonest facies present in Unit 3 and consists of poorly sorted, grain- to matrixsupported pebble to cobble conglomerates (Figs 13E and 16A). Mean clast size range is 5 to $12 \mathrm{~cm}$ and maximum size reaches 60 to $80 \mathrm{~cm}$. Clasts have both sedimentary pre-rift and basement sources. Rounded to subrounded carbonate clasts derived from the Paleogene carbonate sequence (Fig. 3) are the most abundant, while subangular to subrounded chert clasts are probably sourced from chert bands in the Thebes Formation. Subangular to angular igneous-metamorphic clasts form up to $\sim 20 \%$ of the deposits. The matrix fraction is composed of moderately to very well sorted medium to very coarse sandstone. Beds are either tabular, with slightly concave to planar irregular bases and planar tops, or lenticular, with pronounced concave bases and planar tops. Tabular beds range from 0.6 to $3.5 \mathrm{~m}$ in thickness. Lenses are 1.8 to $4 \mathrm{~m}$ thick and show distinctive erosive bases over finer-grained facies. The conglomerates are massive to crudely stratified. Internal differences in clast concentration give rise to sandier lenses 2 to $3 \mathrm{~m}$ wide and up to $0.5 \mathrm{~m}$ thick within the conglomerate bodies. Large-scale cross-sets are developed at or towards the base of the conglomerate succession, dipping towards NW (Log 6; Fig. 10). They are 1.5 to $2 \mathrm{~m}$ high and downlap onto fine to very fine-grained sandstones (Facies 4A, see below) south of Wadi Feiran (Fig. 16D), while they reach 4 to $10 \mathrm{~m}$ high in the northern exposures (Figs $16 \mathrm{~B}$ and C) and downlap onto siltstones and mudstones (Facies 2 and 4D; Figs 10 and 12).

\section{Facies 3B (interbedded matrix-supported conglomerates and sandstones)}

Facies 3B comprises poorly sorted, grain- to matrix-supported coarse to very coarse pebble conglomerates intercalated with well sorted medium- to very coarse-grained sandstones in successions 1.5 to $4.5 \mathrm{~m}$ thick (Fig. 13E). The conglomerates occur as tabular beds 20 to $30 \mathrm{~cm}$ thick, in which mean clast size range is 5 to $12 \mathrm{~cm}$ and maximum size varies from 20 to $30 \mathrm{~cm}$. The sandstones occur as laminated or massive tabular beds 20 to $50 \mathrm{~cm}$ thick with floating pebbles.

\section{Facies 3C (cobbly and pebbly sandstones)}

Sandstones in this unit generally occur as 0.4 to $1.8 \mathrm{~m}$ thick tabular beds with planar bases and tops, variably eroded by Facies 3A deposits (Fig. 13E). They are composed of well sorted grain supported medium to very coarse sandstones, and are laminated or massive, often with floating pebbles or cobbles.

This article is protected by copyright. All rights reserved. 


\section{Interpretation}

The general coarse grained nature of this unit reflects overall high energy conditions in the depositional environment, and the poorly sorted pebble to cobble conglomerates in particular (Facies $3 \mathrm{~A}$ and $3 \mathrm{~B}$ ) are consistent with deposition from non-cohesive debris flows (cf. Sohn et al., 1999; Sohn 2000; Dasgupta, 2003). The erosive surfaces at the base of the conglomerate deposits may indicate that erosion of the substrate by traction currents predated the debris flow deposition events. Alternation of the conglomerates with laminated and massive sandstone beds indicates variations in energy conditions and fluctuations in the input of coarse clastic material into the depositional system, with the laminated sandstones themselves providing evidence of traction sedimentation associated with more dilute flows (Sohn et al., 1999; Sohn 2000). Floating pebbles and cobles in the sandstone facies are related to debris-fall processes. Unit 3 facies characteristics are consistent with those of coarse-grained deltas (e.g. McPherson et al., 1987; Sohn 2000; Blair \& McPherson, 2008). The large-scale cross-sets constitute deltaic clinoforms (e.g. Postma, 1990), indicating shallow-water conditions south of Wadi Feiran and an increasing bathymetry to the north and the clast shapes observed show an overall roundness typical of marine environments (e.g. Massari \& Parea, 1988). Nevertheless, as no subaerial counterpart has been detected in the study area it is not possible to establish whether Unit 3 was a fan delta or fluvial delta (McPherson et al., 1987; Blair \& McPherson, 2008). The absence of marine, tidal or wave, structures favours a coarsegrained deltaic environment where alluvial processes dominated over marine ones (Blair \& McPherson, 2008). The fine grained facies (mudstones and siltstones) intercalated with the conglomerate successions represent offshore to offshore transitional environments.

\section{Unit 4 (sandstone-dominated)}

This extensive sandstone dominated unit is continuously exposed for about $12 \mathrm{~km}$ along the dipslope, on the eastern margin of Wadi Withr (Figs 4, 5 and 11). Unit 4 is characterised by a tabularsheet geometry (Figs 5D, 7B, 7C, 10 and 11). It is bounded by a sharp planar and erosive base interpreted as a regressive surface of marine erosion over Unit 2 deposits in Wadi Withr (Figs 4 and 11) and directly on top of Unit 1 south of Wadi Feiran (Figs 4 and 10). In general, a clear trend is observed in the grain-size distribution along the strike of Unit 4 deposits, where sand-dominated facies predominate in the SSE (Logs 1, 2 and 7 to 12; Figs 10 and 11), and are progressively replaced by finer grained facies to the NNW (Logs 13 to 20; Fig. 11). Unit 4 shows an increase in thickness and reduction in grain size of the deposits down the dipslope (Logs 1 to 2; Fig. 10). Key stratal surfaces are particularly well preserved and continuous throughout the exposures of the Wadi Withr area (Logs 7 to 20; Fig. 10).

This article is protected by copyright. All rights reserved. 
Well developed channelized sandstone bodies (Facies 4B) are exposed for about $2 \mathrm{~km}$ on the eastern margin of Wadi Withr to the north of Wadi Feiran, opposite the exposures of Unit 3 (Figs 4, 10 and 11). They are interbedded with bioturbated sandstones (Facies $4 \mathrm{~A}$ ), thinning until they completely pinch out towards the NNW (between logs 9 and 10; Fig. 11).

\section{Facies $4 A$ (bioturbated sandstones)}

This is the dominant facies in Unit 4, comprising moderately to well sorted, very fine- to mediumgrained, strongly bioturbated sandstones (Bioturbation Index 5-6) (Figs 13D, 17A, 17B and 17C). Sedimentary structures, including low angle erosion surfaces and cross bedding, cross lamination and relic wave ripples, are locally preserved, but the sandstones generally have a mottled to structureless appearance associated with a diverse and abundant ichnofauna. Echinoid burrows form a mottled texture, and may contain the crushed shell debris. Rare shell lags dominated by gastropods with subordinate disarticulated bivalves and echinoid spines can be traced for $1 \mathrm{~km}$ and are generally only one shell thick. Sharks' teeth and echinoid body fossils, both infaunal and epifaunal, are abundant throughout the facies, and arthropod remains, bivalves, bryozoa, and coral fragments also occur, but are rare. Carbonate nodules up to $15 \mathrm{~cm}$ in diameter give a nodular appearance and laterally continuous carbonate-cemented beds 10 to $20 \mathrm{~cm}$ thick are common. Horizontal burrows including Planolites isp. and Gyrochortes isp. are commonly overprinted by burrows with a dominant vertical component, such as silt-lined Palaeophycus isp. and Ophiomorpha isp. descending from these carbonate-cemented bounding surfaces. Unlined Thalassinoides isp. burrows may descend up to $1.5 \mathrm{~m}$ into the sediment beneath, overprinting the lined burrows. Thalassinoides isp. burrows often have a coarse sandstone fill and can be carbonate cemented.

\section{Facies $4 B$ (channelized sandstones)}

This facies is made up of very well sorted medium to very coarse sandstones that occur in vertically stacked channelized sandbodies up to $5 \mathrm{~m}$ thick (Figs 13D, 17D and 17E). The sandstones contain variable amounts of shell debris and isolated floating, entire but disarticulated shells 1 to $6 \mathrm{~cm}$ in length are common. Metre-scale trough-crossed bedding is the dominant structure in the channels and simple planar-crossed bedding is subordinately developed. The channel geometry is characteristically lenticular with some wedges defined between eroding channels. Channels can be divided into two groups according to their dimensions and fill characteristics. The smaller scale ones are up to $1.5 \mathrm{~m}$ thick with a variable height-to-width ratio of up to $1: 5$, and they are filled by trough-

This article is protected by copyright. All rights reserved. 
crossed bedding and have simple concave bases and planar tops. The thicker channels ( 2 to $5 \mathrm{~m}$ ) have height-to-width ratios closer to $1: 3$ and are 10 to $15 \mathrm{~m}$ wide. These channels show multiphase filling and are strongly erosive into underlying deposits (commonly Facies $4 \mathrm{~A}$ ) with complex erosional relief on their basal surface. Syn-sedimentary soft sediment deformation, such us folding and overturned bedding is also observed at the base of the thickest channels. Channel axes orientation ranges predominantly between NNW and NE (Log 7; Fig. 10). Bioturbation is moderate to intense in both types of channels. Vertical burrows tend to dominate, in particular those of Ophiomorpha isp.

\section{Facies $4 \mathrm{C}$ (heterolithics)}

Millimetre-scale alternations of laminated mudstone, siltstone and sandstone typify this facies (Fig. 13C). They form tabular beds 5 to $50 \mathrm{~cm}$ thick with sharp bases and tops. Sandstones with swaley cross-stratification appear intercalating silt/mud beds with wavy lamination, arranged in 20 to $30 \mathrm{~cm}$ thick beds. Soft sediment deformation related to centimetre-scale slumps and slides and water escape structures is present. Floating isolated bioclasts and lithoclasts 0.2 to $5 \mathrm{~cm}$ long are present, and bioclasts and lithoclasts form rare thin lenses, 1 to $5 \mathrm{~cm}$ thick and up to $1.5 \mathrm{~m}$ wide within the heterolithic succession.

The heterolithic deposits commonly alternate with 10 to $20 \mathrm{~cm}$ thick clean sandstones, forming cycles in the order of $1.5 \mathrm{~m}$ in thickness (Fig. 13C). These sandstones are highly bioturbated by Ophiomorpha isp., Thalassinoides isp. and Planolites isp. burrows that penetrate up to $20-30 \mathrm{~cm}$ into the underlying heterolithic facies. These sandstones are very well sorted, grain-supported, fineto medium-grained and usually contain a large proportion of variably broken shells.

\section{Facies $4 D$ (mudstone lenses)}

This is the finest-grained facies of Unit 4 and is developed as mudstone-dominated lensoidal bodies generally less than $15 \mathrm{~m}$ thick that extend along strike the dipslope for several kilometres intercalating with Facies $4 \mathrm{~A}$ and $4 \mathrm{C}$ deposits (Fig. 11) and with Unit 3 deposits (Fig. 10). The mudstones compose laminated tabular beds up to $10 \mathrm{~cm}$ thick with planar bases and tops. Subordinate siltstones and very fine to medium grained sandstones are observed composing 1 to 5 $\mathrm{cm}$ thick laminated, cross-laminated and massive tabular beds. Facies 4D deposits are affected by moderate to intense bioturbation, especially by Chondrites isp., Planolites isp. and Skolithos isp.

This article is protected by copyright. All rights reserved. 
Where Facies 4D intercalates with Unit 3 deposits it consists of finely laminated intercalations of siltstone and mudstone ( $\sim 10 \mathrm{~m}$ thick) or mudstone intervals ( $\sim \mathrm{m}$ thick) with floating pebbles (Fig. 13E). Poorly sorted, matrix-supported medium pebble conglomerates are intercalated with the mudstones, forming isolated lenses $10 \mathrm{~cm}$ thick and 2 to $3 \mathrm{~m}$ in length.

\section{Interpretation}

A common feature of these four facies is the moderate to intense degree of bioturbation, which indicates a well oxygenated environment with a plentiful supply of nutrients. The sandy, highly bioturbated and relatively clean deposits of Facies $4 \mathrm{~A}$ were deposited in a moderately energetic environment, in which biogenic reworking resulted in only limited preservation of the physical sedimentary structures. Although the preservation of sedimentary structures is imperfect, the relic ones found are indicative of traction currents. The abundance of biogenic structures, the scarce unequivocal signs of wave action found (e.g. wave ripples) and the preserved ichnogenera evidence a lower shoreface depositional environment (e.g. Gowland, 1996; Clifton, 2006; MacEachern et al., 2007). The presence of shell lags and carbonate cemented horizons are interpreted as omission surfaces.

The coarser grain size in Facies $4 \mathrm{~B}$ is suggestive of relatively higher energy environments than for Facies 4A. The well developed unidirectional tractive structures, channelized geometries of the rock bodies and grain sorting point to the predominance of fluid erosive currents. The fact that Facies $4 \mathrm{~B}$ are eroded into Facies $4 \mathrm{~A}$ show that local higher energy conditions were established through unidirectional traction currents developed on the lower shoreface. The paleoflow orientations obtained are mainly distributed from NNW to NE, subparallel to oblique to the dipslope strike. The presence of syn-sedimentary deformational structures is possibly related to gravitational instability of the channel walls.

The variations in grain size observed in Facies $4 C$ suggest variable energetic conditions ranging from low to moderate. The higher content of bioclasts in the sandstone beds suggests a shallower provenance. The development of swaley cross-stratification indicates deposition between fair weather and storm wave base (Dumas \& Arnott, 2006). This facies is interpreted as deposited in an offshore transitional setting influenced by storms (e.g. Gowland, 1996; Clifton, 2006).

This article is protected by copyright. All rights reserved. 
Facies $4 \mathrm{D}$ is interpreted to reflect proximal offshore conditions (see Unit 2 sedimentary processes section) and represents the lowest energy member of Unit 4 facies. Its preservation is mainly limited to the northern areas of Wadi Withr (Logs 12 to 20; Fig. 11) and two lenses north of Wadi Feiran (Logs 6 and 7; Figs 10 and 11).

Unit 4 main sedimentary characteristics represent a relatively low gradient marine environment dominated by siliciclastic deposition, where a complete passage from lower shoreface to offshore deposition occurred along the strike of the dipslope, from SSE to NNW. The marine flooding surfaces and regressive surfaces of marine erosion tracked along Wadi Withr and north of Wadi Feiran (Logs 7 to 20; Fig. 11) are interpreted to reflect shifting of the shoreline position on the dipslope during deposition of Unit 4. Thus, defining accommodation space controlled parasequences.

\section{DISCUSSION: CONTROLS ON DIPSLOPE SEDIMENTATION}

Previous studies based on subsurface data recognise tilting of the hangingwall as a determinant in the depositional style and environments developed on the dipslope (Ravnås \& Bondevik, 1997; Ravnås \& Steel, 1997, 1998; Nøttvedt et al., 2000). Similarly, it is the tilting of the hangingwall towards ENE that defines the overall stacking geometry of the stratigraphic units in the dipslope of the EQFB. However, some of the most important paleoenvironmental variations in the syn-rift occur along strike on the dipslope. For example, Unit 1 shows subtle thickening towards the SSE, Unit 2 thins towards the SSE until it pinches out around Wadi Feiran, Units 3 and 4 facies deepen towards the NNW, and Unit 3 thickens towards the NNW (Figs 5E, 10 and 11). As the pre-rift units are interpreted to have been horizontal and near sea level at the time the rifting began (Garfunkel \& Bartov, 1977; Moustafa, 1993; Bosworth \& McClay, 2001; Moustafa, 2004; Bosworth et al., 2005), the observed pattern of erosion developed at the base of the syn-rift succession along the dipslope strike (Fig. 9) suggests that the overall initial transgression was diachronous, younging along the strike of the dipslope from NNW to SSE, approximately parallel to the EQFB main boundary structures. The paleobathymetry of the sedimentary units deepens not only down dip towards ENE, but also along the strike of the dipslope, from SSE to NNW, resulting in a configuration that persisted in the dipslope area from rift initiation until at least the deposition of Unit 4.

This article is protected by copyright. All rights reserved. 


\section{Dipslope tilting and tectono-sedimentary evolution}

\section{First phase of tilting}

The first phase of tilting corresponds to syn-rift initiation in the EQFB dipslope area. The truncation of the pre-rift units observed along the strike of the dipslope (Fig. 9) is interpreted to originate from small variations in the tilt of the pre-rift during vertical fault propagation folding and the lateral propagation of the faults along the Coastal Fault Belt towards SSE (Fig. 18A), causing uplift of the Coastal Fault Belt crest towards NNW while the hangingwall block tilted $\sim 40$ towards the ENE. As a consequence, the initial marine transgression created an elongated embayment that propagated parallel to the EQFB margins. Coastal erosion of the hangingwall block occurred both up-dip and along the strike of the dipslope following the direction of transgression. The observed NE orientation of the conglomerate lenses at the base of Unit 1 are consistent with the existence of surface gradients transverse or oblique to the strike of the dipslope. Similar funnelling of sedimentary systems along the long axes of half-grabens is also observed on the embryonic synclinal depocentres developed at the Eastern Boundary Fault Belt (Lewis et al., 2015).

\section{Deposition after tilting 1}

The near-coincidence in attitude between the pre-rift/syn-rift boundary and Unit 1 bedding (Fig. 8) indicates that no further tilting occurred between erosion of the pre-rift substrate and the deposition of Unit 1 for any given position along the dipslope. Deposition during this phase (Fig. 18A) is characterised by lack of terrigenous clasts, which speaks for both the transgressive conditions in the environment and lack of any well developed drainage system on the dipslope area. It is interpreted that the dipslope was an area of subdued topography that originated from the tilting and uplift of the hangingwall during the first phase of tilting.

\section{Second phase of tilting}

The second phase of tilting involves $\sim 3.5 \circ$ of tilt of the hangingwall block between units 1 and 3 (Fig. 18B). The change from Unit 1 to Unit 2 is abrupt and corresponds to a sudden change in environmental conditions from a high energy shallow marine setting to a low energy offshore one. The coincidence of this tilting phase with generalised deepening of the dipslope area suggests that the relative rise in sea level was at least partly triggered by the tilting of the hangingwall block. It is possible, however, that the effects of tilting were enhanced by a regional rise in sea level due to the

This article is protected by copyright. All rights reserved. 
basin-scale increase in subsidence rate experienced by the Suez Rift during this time (e.g. Colleta et al., 1988; Richardson \& Arthur, 1988; Steckler et al., 1988; Patton et al., 1994; Bosworth \& McClay, 2001). Deepening and thickening of Unit 2 towards both the ENE and NNW (Figs 5E, 10 and 12) reveals a palaeobathymetric pattern similar to that interpreted for the previous phases. Although the backtilting of the EQFB hangingwall block should have uplifted the Coastal Fault Belt crest generating a possible source area, no deposits have been found on the dipslope that can be related to the erosion of the footwall crest during this phase. The footwall crest is thus interpreted to have consisted of a narrow footwall island of relatively low relief that extended along strike and widened towards the SSE (Fig. 18B). The predominance of mudstones and the relative absence of coarsegrained lithologies in Unit 2 point to sediment-starved conditions around the EQFB hangingwall dipslope. The composition of the eroding footwall crest may also have placed constraints on the depositional systems during this phase. The upper $525 \mathrm{~m}$ of pre-rift stratigraphy are mainly composed of fine-grained carbonates (Fig. 3), erosion of which would have produced material that could be transported to the deeper parts of the depocentre (i.e. further down the dipslope), thereby starving the shallower areas of the dipslope.

\section{Deposition after tilting 2}

Units 3 and 4 reflect deposition in shallower and higher energy conditions than Unit 2 (Fig. 18C). The absence of significant angular unconformities (i.e. $>1^{\circ}$ ) between Units 3 and 7 suggests that tilting of the hangingwall block was negligible during this time and that tectonic activity along the EQFB as a whole can therefore be considered lower than during the deposition of Unit 2. The regional erosive, non-angular unconformity at the base of units 3 and 4 may therefore be associated with a relative fall in sea level unrelated to local tectonic activity on the EQFB hangingwall. Accordingly, the base level variation cycles observed in the Unit 4 exposures along Wadi Withr (Fig. 10) are interpreted to have been triggered mainly by regional controls. The footwall island that resulted from the emergence of the Coastal Fault Belt crest is interpreted to have widened since the second phase of tilting due to the relative fall in sea level (Fig. 18C).

Intercalation of units 3 and 4 on the southern margin of Wadi Feiran suggests that these units were lateral equivalents and their deposition was more or less contemporaneous (Fig. 10). Geometry, internal architecture and paleoflow directions indicate that the source area of Unit 3 was situated to the SW, and the subangular to angular igneous-metamorphic clasts in Facies $3 \mathrm{~A}$ suggest that basement rocks were exposed to the SW of the study area during deposition. Present-day

This article is protected by copyright. All rights reserved. 
exposures of basement units along the dipslope (Fig. 2) are due to significant tilting ( 7 을 of the EQFB postdating the deposition of Unit 7. Given the sedimentary pre-rift thickness in the area ( $\sim 1800 \mathrm{~m}$ ), the degree of tilting of the EQFB hangingwall during phases 1 and 2 ( 7.5ㅇ) is insufficient to account for basement exposure along the dipslope. A more likely explanation lies in the presence of basement fault blocks to the SW of the dipslope area that could have supplied basement clasts to the EQFB. Age-equivalent deposits in the subsurface immediately to the west of the dipslope along the coast have basement provenance (Dancer et al., 2010) and in some areas the basement is interpreted to be immediately overlain by syn-rift deposits (e.g. Sayed, 1962 in Robson, 1971; Robson, 1971; Evans, 1990; Dancer et al., 2010).

Unit 4 facies organization shares a similar deepening pattern with the previous units. Nevertheless, it preserves a rather tabular geometry along strike north of Wadi Feiran and only thins to the south of it. The presence of quartz grains in this unit and age-equivalent units in the Suez Rift is interpreted to reflect a provenance from the Nubia Sandstones (e.g. Garfunkel and Bartov, 1977; Evans, 1990; Patton et al., 1994; Dancer et al., 2010). While the great thickness of the Nubia Sandstones makes it plausible that they were exposed on the dipslope for the amount of tilting of the EQFB hangingwall prior to the deposition of units 3 and $4\left(\sim 7.5^{\circ}\right)$, there is currently no further evidence to support the possibility.

It is important to note that, while syn-rift deposits derived from the Nubia Sandstone are regionally recognised in the Suez Rift for Unit 4 time-equivalent strata, no basement-derived conglomerates of this age are known to be exposed along the eastern rift flank. Moreover, the cases of basement-derived conglomerates in the EQFB are all found to be sourced from the rift shoulder to the east (e.g. Garfunkel and Bartov, 1977; Garfunkel, 1988; Evans, 1990; Gawthorpe et al., 1990; Patton et al., 1994; Bosworth \& McClay, 2001). Unit 3 not only occupies a lower stratigraphic position than those cited cases but also is derived from sources internal to the rift.

\section{Third phase of tilting and deposition}

The 70 dip of the topset of Unit 7 evidences the third phase of tilting of the EQFB hangingwall. No marine deposits are preserved above Unit 7 and only subhorizontal Quaternary alluvial, aeolian and colluvial deposits lie unconformably on top of Unit 7. Thus, the third phase of tilting is interpreted to represent the emergence of the Suez Rift marginal depocentres that occurred towards the Upper Miocene-Pliocene as a result of uplift of the rift shoulders and nucleation of fault displacement along

This article is protected by copyright. All rights reserved. 
the present day coast (Garfunkel and Bartov, 1977; Garfunkel, 1988; Colleta et al., 1988; Richardson \& Arthur, 1988; Steckler et al., 1988; Bosworth \& McClay, 2001).

A major characteristic of syn-rift marine successions deposited on a hangingwall dipslope is the occurrence of disconformities and angular unconformities that diverge basinwards, away from the footwall crest (Ravnås \& Bondevik, 1997; Ravnås \& Steel, 1997, 1998; Nøttvedt et al., 2000). In that context, Unit 2 is comparable to the "rotational tilt packages (high tilt rates)" while units 3 and 4 are comparable to the "tectonic quiescence packages (low tilt rates)" of Ravnås \& Steel (1998). In particular, the arrangement of units 2, 3 and 4 in the EQFB is comparable to the regressive and transgressive segments described for the middle Heather member and Fensfjord Formation in the Brage area of the North Sea rift basin (Ravnås \& Bondevik, 1997).

Published measurements of hangingwall tilting are relatively scarce. Nøttvedt et al. (2000) constrained the tilting of the hangingwall at Snorre-H in the North Sea rift basin for the following intervals: 3 o between the tops of Brent Group and Heather Formation, $\sim 20$ between the tops of Heather and lower Draupne formations and $\sim$ $\%$ between the lower and top Draupne Formation. Leeder et al. (2005) measured a tilting of 3.9 o in the Alkyonides hangingwall in the Corinth rift basin, where sediment thickness varies from 59 to $233 \mathrm{~m}$ down the dipslope. Although these measurements are similar to the first and second phases of tilting in the EQFB, the Snorre-H hangingwall extends for about 30 to $50 \mathrm{~km}$ between its boundary fault systems whereas the EQFB and Alkyonides hangingwall dipslopes extend for only $12-15 \mathrm{~km}$. More work is needed combining values of hangingwall tilting, fault displacement and footwall uplift in half-grabens of different sizes in order to achieve a better understanding of the interplay between these parameters. Especially important is to assess how much of the fault displacement is effectively translated in tilting of the hangingwall block. The detailed sedimentary observations obtained for the case of the EQFB dipslope over well exposed and continuous large scale outcrops on the location and orientation of the sedimentary systems developed in the dipslope, together with the distribution of grain-sizes among their deposits, is of particular relevance to subsurface studies relying on seismic imaging resolution (tens of $\mathrm{m}$ ) and sparsely located wells ( $\mathrm{km}$ apart). This denotes also the necessity of integrating surface studies with digital outcrop techniques in order to generate analogue models that can aid applying the observations to other areas.

This article is protected by copyright. All rights reserved. 


\section{CONCLUSIONS}

Hangingwall block tilting was a major control on the sedimentary syn-rift evolution of the Miocene marine dipslope area of the El Qaa Fault Block. This tilting of the hangingwall caused not only marked differences in facies development and thickness of the deposits down the dipslope, but also along the dipslope strike.

The tilting history of the dipslope can be divided into three phases.

- The first phase of tilting tilted the pre-rift strata by $\sim 40$, marking the syn-rift initiation. An ensuing marine transgression progressed up dip, oblique to the dipslope strike, truncating the pre-rift strata. The direction of the transgression is interpreted to result from the coupled effect of tilting of the hangingwall and the fault propagation at the Coastal Fault Belt.

- The second phase of tilting accounted for $\sim 3.5$ o of tilting, triggering the deepening of the dipslope from shallow marine to offshore conditions. Subsequent regression caused by a regional fall in base level led to the establishment of a coarse-grained delta system in a low gradient marine coastal environment.

- The third phase accounts for 7 으 of tilting. This affected the whole of the syn-rift stratigraphy of the dipslope and occurred in post-Miocene times.

Variations in basin physiography and syn-rift stratigraphic architecture along strike the dipslope can be persistent throughout the syn-rift evolution of a half-graben. In the El Qaa Fault Block case the sedimentary environments developed along the strike of the dipslope present variations in gradients and bathymetric patterns observed from early syn-rift till rift climax.

\section{ACKNOWLEDGEMENTS}

We would like to thank Farah (Yossef) Barakat and Bilal Gooda for their invaluable logistical support and friendship. This study was possible thanks to a post-doctoral research project granted to MM by 'VISTA - A basic research partnership between Statoil and the Norwegian Academy of Science and Letters' and phase 2 of The Rift Analogues Project (TRAP) granted to RLG and DH, sponsored by

This article is protected by copyright. All rights reserved. 
ConocoPhillips and Statoil. Ian Carr is acknowledged for his initial work in the study area. Jonathan (Joss) Smith, John Stevenson and Xavier Van Lanen are thanked for their assistance in the field. Catherine Hunt is acknowledged for helping with the language editing of the manuscript. Comments and suggestions from an anonymous reviewer, Tannis McCartney and Journal Editor C. J. Ebinger improved the manuscript.

\section{REFERENCES}

Allam, A. \& Khalil, H. (1989) Geology and Stratigraphy of Gebel Qabeliat Area, Southwestern Sinai, Egypt. J. Af. Earth Sci., 9, 59-67.

Blair, T.C. \& McPherson, J.G. (2008) Quaternary sedimentology of the Rose Creek fan delta, Walker Lake, Nevada, USA, and implications to fan-delta facies models. Sedimentology, 55, 579-615.

Bosworth, W. \& McClay, K.R. (2001) Structural and stratigraphic evolution of the Gulf of Suez rift, Egypt. In: Peri-Tethys Memoir 6: Peri-Tethyan Rift/Wrench Basins and Passive Margins (Ed. by P.A. Ziegler, W. Cavazza, A.H.F. Robertson \& S. Crasquin-Soleau), Mémoires du Muséum National d' Histoire Naturelle de Paris, Paris, pp. 567-606.

Bosworth, W., Huchon, P. \& McClay, K.R. (2005) The Red Sea and Gulf of Aden Basins. J. Af. Earth Sci., 43, 334-378.

Cattaneo, A. \& Steel, R.J. (2003) Transgressive deposits: a review of their variability. Earth-Sci. Rev., 62, 187-228.

Clifton, H.E. (2006) A re-examination of facies models for clastic shorelines. In: Facies Models Revisited (Ed. by H.W. Posamentier and R.G. Walker), SEPM Spec. Publ. 84, 293-337.

This article is protected by copyright. All rights reserved. 
Colletta, B., Le Quellec, P., Letouzey, J. \& Moretti, I. (1988) Longitudinal evolution of the Suez rift structure (Egypt). Tectonophysics, 153, 221-233.

Cowie, P.A., Attal, M., Tucker, G.E., Whittaker, A.C., Naylor, M., Ganas, A. \& Roberts, G.P. (2006) Investigating the surface process response to fault interaction and linkage using a numerical modelling approach. Basin Res., 18, 231-266.

Dancer, P.N., Collins, J., Beckly, A., Johnson, K., Campbell, G., Mumaw, G. \& Hepworth, B. (2010) Exploring subtle exploration plays in the Gulf of Suez. In: Proceedings of the 7th Petroleum Geology Conference (Ed. by B.A. Vining \& S.C. Pickering), Geological Society, London, pp. 771781

Dasgupta, P. (2003) Sediment gravity flow - the conceptual problems. Earth-Sci. Rev., 62, 265-281.

Dumas, S. \& Arnott, R.W.C. (2006) Origin of hummocky and swaley cross-stratification - The controlling influence of unidirectional current strength and aggradation rate. Geology, 34, 1073-1076.

Elliott, G.M., Jackson, C.A.L., Gawthorpe, R.L., Wilson, P., Sharp, I.R., \& Michelsen, L. (2015) Late synrift evolution of the Vingleia Fault Complex, Halten Terrace, offshore Mid-Norway; a test of rift basin tectono-stratigraphic models. Basin Res., doi: 10.1111/bre.12158.

Evans, A.L. (1990) Miocene sandstone provenance relations in the Gulf of Suez: Insights into synrift unroofing and uplift history. AAPG Bull., 74, 1386-1400.

Garfunkel, Z. (1988) Relation between continental rifting and uplifting: evidence from the Suez rift and northern Red Sea. Tectonophysics, 150, 33-49.

This article is protected by copyright. All rights reserved. 
Garfunkel, Z. \& Bartov, Y. (1977) The tectonics of the Suez Rift. Geol. Surv. Israel Bull., 71, 1-41.

Gawthorpe, R.L., \& Leeder, M.R. (2000) Tectono-sedimentary evolution of active extensional basins. Basin Res., 12, 195-218.

Gawthorpe, R.L., Hurst, J.M. \& Sladen, C.P. (1990) Evolution of Miocene footwall-derived coarsegrained deltas, Gulf of Suez, Egypt: Implications for exploration. AAPG Bull., 74, 1077-1086.

Gupta, S., Underhill, J.R., Sharp, I.R. \& Gawthorpe, R.L. (1999) Role of fault interactions in controlling synrift sediment dispersal patterns: Miocene, Abu Alaqa Group, Suez Rift, Sinai, Egypt. Basin Res., 11, 167-189.

Gowland, S. (1996) Facies characteristics and depositional models of highly bioturbated shallow marine siliciclastic strata: an example from the Fulmar Formation (Late Jurassic), UK Central Graben. In: Geology of Humber Group: Central Graben and Moray Firth, UKCS (Ed. by A. Hurst, H.D. Johnson, S.D. Burley, A.C. Canham, \& D.S. Mackertich), Geol. Soc. of London Spec. Publ., $114,185-214$.

Hodgetts, D. (2009) LiDAR in the environmental sciences: geological applications. In: Laser Scanning for the Environmental Sciences (Ed. by G. Heritage \& A. Large), 165-179. Wiley-Blackwell, Oxford.

Kidwell, S.M. (1991) Condensed deposits in siliciclastic sequences: Expected and observed features. In: Cycles and Events in Stratigraphy (Ed. by G. Einsele, W. Ricken \& A. Seilacher), pp. 682-695. Springer-Verlag, Berlin.

This article is protected by copyright. All rights reserved. 
Krebs, W.N., Wescott, W.A., Nummedal, D., Gaafar, I., Azazi, G. \& Karamat, S.A. (1997) Graphic correlation and sequence stratigraphy of Neogene rocks in the Gulf of Suez. B. Soc. Géol. Fr., $168,63-71$.

Leeder, M.R. \& Jackson, J.A. (1993) The interaction between normal faulting and drainage in active extensional basins, with examples from the western United States and central Greece. Basin Res., 5, 79-102.

Leeder, M.R., Mack, G.H. \& Salyards, S.L. (1996) Axial-transverse fluvial interactions in half-graben: Plio-Pleistocene Palomas Basin, southern Río Grande Rift, New Mexico, USA. Basin Res., 12, 225-241.

Leeder, M.R., Portman, C., Andrews, J. E., Collier, R.E.L., Finch, E., Gawthorpe, R.L., McNeill, L.C., Pérez-Arlucea, M. \& Rowe, P. (2005) Normal faulting and crustal deformation, Alkyonides Gulf and Perachora peninsula, eastern Gulf of Corinth rift, Greece. J. Geol. Soc. London, 162, 549561.

Lewis, M.M., Jackson, C.A.L., \& Gawthorpe, R.L. (2015) Tectono-sedimentary development of early syn-rift deposits: The Abura Graben, Suez Rift, Egypt. Basin Res., doi: 10.1111/bre.12151

MacEachern, J.A., Bann, K.L., Pemberton, S.G. \& Gingras, M.K. (2007) The ichnofacies paradigm: high-resolution paleoenvironmental interpretation of the rock record. In: Applied Ichnology (Ed. by J.A. MacEachern, K.L. Bann, M.K. Gingras \& S.G. Pemberton), SEPM Short Course Notes 52, 27-64.

Massari, F. \& Parea, G.C. (1988) Progradational gravel beach sequences in a moderate- to highenergy, microtidal marine environment. Sedimentology, 35, 881-913.

This article is protected by copyright. All rights reserved. 
McPherson, J.G., Shanmugam, G. \& Moiola, R.J. (1987) Fan-deltas and braid deltas: Varieties of coarse grained deltas. Geol. Soc. Am. Bull., 99, 331-340.

Moustafa, A.R. (1993) Structural characteristics and tectonic evolution of the east-margin blocks of the Suez rift. Tectonophysics, 223, 381-399.

Moustafa, A.R. (1996) Internal structure and deformation of an accommodation northern part of the Suez rift. J. Struct. Geol., 18, 93-107.

Moustafa, A.R. (1997) Controls on the development and evolution of transfer zones: the influence of basement structure and sedimentary thickness in the Suez rift and Red Sea. J. Struct. Geol., 19, 755-768.

Moustafa, A.R. (2004) Geological Maps of the Eastern Side of the Suez Rift (Western Sinai Peninsula) Egypt. AAPG Datapages, GIS Series 74.

Muravchik, M., Bilmes, A., D’Elia, L., \& Franzese, J.R. (2014). Alluvial fan deposition along a rift depocentre border from the Neuquén Basin, Argentina. Sed. Geol., 301, 70-89.

Nøttvedt, A., Berge, A.M., Dawers, N.H., Færseth, R.B., Häger, K.O., Mangerud, G. \& Puigdefabregas, C. (2000) Syn-rift evolution and resulting play models in the Snorre-H area, northern North Sea. In: Dynamics of the Norwegian margin (Ed. by A. Nøttvedt), Geol. Soc. of London Spec. Publ., 167, 179-218.

Patton, T.L., Moustafa, A.R., Nelson, R.A. and Abdine, S.A. (1994) Tectonic evolution and structural setting of the Suez Rift. In: Interior Rift Basins (Ed. by S.M. Landon), AAPG Mem., 59, 7-55.

This article is protected by copyright. All rights reserved. 
Postma, G. (1990). Depositional architecture and facies of river and fan deltas: a synthesis. In: Coarse-Grained Deltas (Ed. by A. Colella \& D.B. Prior), IAS Spec. Publ., 10, 13-27.

Rarity, F., van Lanen, X.M.T., Hodgetts, D., Gawthorpe, R.L., Wilson, P., Fabuel Perez, I. \& Redfern, J. (2014) Lidar-based digital outcrops for sedimentological analysis: workflows and techniques. In: Sediment Body Geometry and Heterogeneity: Analogue Studies for Modelling the Subsurface (Ed. By A.W. Martinius, J.A. Howell, \& T.R. Good), Geol. Soc. of London Spec. Publ., 387, 153-183.

Ravnås, R. \& Bondevik, K. (1997) Architecture and controls on Bathonian-Kimmeridgian shallow marine synrift wedges of the Oseberg-Brage areas, northern North Sea. Basin Res., 9, 197-226.

Ravnås, R. \& Steel, R.J. (1997) Contrasting styles of Late Jurassic syn-rift turbidite sedimentation: a comparative study of the Magnus and Oseberg areas, northern North Sea. Mar. Petrol. Geol., 14, 417-449.

Ravnås, R. \& Steel, R.J. (1998) Architecture of Marine Rift-Basin Successions. AAPG Bull., 82, 110-146.

Richardson, M. \& Arthur, M.A. (1988) The Gulf of Suez-northern Red Sea Neogene rift: a quantitive basin analysis. Mar. Petrol. Geol., 5, 247-270.

Robson, D.A. (1971) The structure of the Gulf of Suez (Clysmic) rift, with special reference to the eastern side. J. Geol. Soc. London, 127, 247-271.

Sayed, R. (1962) The Geology of Egypt. Elsevier, Amsterdam, 377 pp.

This article is protected by copyright. All rights reserved. 
Sharp, I.R., Gawthorpe, R.L., Armstrong, B. \& Underhill, J.R. (2000) Propagation history and passive rotation of mesoscale normal faults: implications for synrift stratigraphic development. Basin Res., 12, 285-305.

Sohn, Y.K. (2000) Depositional processes of submarine debris flows in the Miocene fan deltas, Pohang Basin, SE Korea with special reference to flow transformation. J. Sed. Res., 70, 491503.

Sohn, Y.K., Rhee, C.W. \& Kim, B.C. (1999) Debris flow and hyperconcentrated flood-flow deposits in an alluvial fan, northwestern part of the Cretaceous Yongdong Basin, Central Korea. J. Geol., 107, 111-132.

Steckler, M.S., Berthelot, F., Lyberis, N. \& Le Pichon, X. (1988) Subsidence in the Gulf of Suez: implications for rifting and plate kinematics. Tectonophysics, 153, 249-270.

Wescott, W.A., Krebs, W.N., Dolson, J.C., Karamat, S.A. \& Nummedal, D. (1996) Rift basin sequence stratigraphy: some examples from the Gulf of Suez. GeoArabia, 1, 343-358.

Young, M.J., Gawthorpe, R.L. \& Sharp, I.R. (2002). Architecture and evolution of syn-rift clastic depositional systems towards the tip of a major fault segment, Suez Rift, Egypt. Basin Res., 14, $1-23$.

Young, M.J., Gawthorpe, R.L. \& Sharp, I.R. (2003) Normal fault growth and early syn-rift sedimentology and sequence stratigraphy: Thal Fault, Suez Rift, Egypt. Basin Res., 15, 479502.

This article is protected by copyright. All rights reserved. 


\section{List of figures and captions:}

Figure 1. (A) Idealized half-graben cross section and its main components. (B) Typical geometry of a half-graben viewed in seismic section. Snorre field, North Sea Basin. (C) Schematic seismic interpretation of reflectors in a hangingwall dipslope and its corresponding geological interpretation (D). (C) and (D) are modified from Ravnås \& Bondevik (1997).

Figure 2. Location maps. (A) Map of the El Qaa Fault Block showing main tectonostratigraphic units and location of the studied area. Plate tectonic setting of the Gulf of Suez region is shown in the map inset. (B) Cross section indicated in (A).

Figure 3. General stratigraphic column for the El Qaa region (Allam \& Khalil, 1989; Moustafa, 2004).

Figure 4. Map of the study area. Cross sections and 2D panel shown in Fig. 5. Progressive truncation towards the WSW of the pre-rift units by the syn-rift sequence can be observed in the southern area of the map, where Unit 1 rests unconformably over the Darat and Thebes formations. Along strike truncation of the Darat Formation towards the NNW is evident from cross-section A-A' through to DD' (Fig. 5).

Figure 5. Cross sections ( $A$ to $D$ ) and reconstructed 2D panel (E). Locations shown in Fig. 4. (E) Panels A and B shown in Figs 10 and 11 respectively. Clinoforms in Unit 7 are schematically represented. Note vertical exaggeration in (E). Progressive truncation of the pre-rift units occurs both up the dipslope towards the Coastal Fault Belt (WSW) and along strike the dipslope towards the NNW.

Figure 6. Stratigraphic units utilised in this study and their correlation with previous lithostratigraphic (cf. Moustafa, 2004) and biostratigraphic (cf. Wescott et al., 1996; Krebs et al., 1997) studies in the area and the tectonostratigraphic evolution of the Suez Rift (Richardson \& Arthur, 1988; Steckler et al., 1988; Patton et al., 1994; Bosworth \& McClay, 2001). Average dip direction and dip values are indicated to the left of the stratigraphic column.

This article is protected by copyright. All rights reserved. 
Figure 7. Field photographs of the dipslope area. (A) Angular unconformity between the pre-rift and syn-rift deposits. Note the truncation of pre-rift strata in the direction of the Coastal Fault Belt towards the west. (B) Oblique view down the dipslope. (C) Along-strike view of the syn-rift units exposed along Wadi Withr. Sedimentary log positions are indicated by black lines and labelled with white circles. For location of the sedimentary logs refer to Fig. 4. Coloured circles indicate the syn-rift units (U1: Unit 1, U2: Unit 2, U3: Unit 3, U4: Unit 4, U5: Unit 5, U6: Unit 6, U7: Unit 7).

Figure 8. Analysis of dip and strike data obtained from the interpretation of the LIDAR datasets. (A) Example of dip and dip direction measurements obtained from the LIDAR datasets. Each dip and dip direction measurement represents the best-fit plane calculated for a series of points manually picked along a marker surface. The plane is represented by a disk, the diameter of which represents the size (area of influence) of the measurement. Two different measurements are shown in this example, represented by the green disks A and B displayed over the triangular mesh. (B) Stereographic projection and close-up view of the plotted dip and dip direction data. The results are synthesised in the chart to the right for each of the analysed surfaces and units. (C) to (G) Frequency diagrams for the size of the dip and dip direction measurements for the pre-rift strata $(C)$, the prerift - syn-rift boundary (D), Unit 1 (E), Units 3 and 4 (F) and the topset of Unit 7 (G).

Figure 9. Pre-rift truncation along strike the dipslope. (A) Map showing the progressive truncation of Mokattam, Darat and Thebes formations towards the NNW. The last exposures along strike the dipslope are indicated by a red arrow labelled $\mathrm{M}$ for the Mokattam Fm base and by a red arrow labelled $D$ for the Darat Fm base. (B) Cross section between points $D$ and $X$, parallel to the dipslope strike. Note the steepening of the boundary between the pre-rift and syn-rift units in the Wadi Feiran area. Very small variations in dip occur within the pre-rift units along the dipslope strike that can occur due to the existence of very small differences in tilting of the hangingwall block along strike the Coastal Fault Belt. Although angular differences lower than $1^{\circ}$ can be easily detected with the methodology used in this study, they lie within the measuring error of the method so care must be taken when interpreting them.

Figure 10. Correlation panel A, $\operatorname{logs} 1,2,6$ and 7. Datum: base of Unit 6 . Note the vertical exaggeration. Rose diagrams represent paleoflow directions measured for Unit 3 in the area corresponding to logs 3, 4, 5 and 6 and for Unit 4 in Log 7. For location of the sedimentary logs and panel refer to Figs 4 and $5 \mathrm{E}$.

This article is protected by copyright. All rights reserved. 
Figure 11. Correlation panel B, logs 7 through to 20. Datum: base of Unit 6 . Note the vertical exaggeration. For location of the sedimentary logs and panel refer to Figs 4 and 5E.

Figure 12. Dip section showing the angular relation between the pre-rift strata and Units 1,2 and 3 . (A) Field photograph. (B) Interpretation. Average dip values are shown for the pre-rift strata and units 1 and 3. White circles correspond to log labels and coloured circles indicate the syn-rift units (U1: Unit 1, U2: Unit 2, U3: Unit 3). The positions of sedimentary logs 4 and 5 are indicated by black lines while the approximate positions of logs 3 and 6 behind the ridge are indicated by arrows. For location of the sedimentary logs refer to Fig. 4. (C) Correlation panel C, logs 3 through to 6. Datum: base of Unit 3. Labelled boxes indicate the relative positions of field photographs shown in Figs. 16B and $16 \mathrm{C}$. Note the wedge-shaped character of Unit 2, thickening down the dipslope towards the ENE.

Figure 13. Sedimentary facies logs. (A) Facies $1 \mathrm{~A}$ at the base of the log section, overlain by Facies $1 \mathrm{~B}$. (B) Facies 2 succession. (C) Facies 4C succession. (D) Succession comprising Facies 4A the base, followed by Facies 4B. (E) Succession comprising Facies 3A, 3B, 3C and 4D. (A), (B), (C), (D) and (E) correspond to actual sections from Logs 1, 3, 2, 7 and 6, respectively (See Figs 4, 10, 11 and 12 for location of the sedimentary logs).

Figure 14. Photographs of the base of the syn-rift succession. (A) Angular unconformity between the pre-rift and syn-rift successions. The contact is highlighted and marked with white arrows. T: truncation, P: parallel contact. (B) Gastrochaenolites isp. burrows developed the top of the prerift. Black triangles indicate the position of the traces. (C) Poorly sorted monolithologic conglomerates (Facies $1 \mathrm{~A}$ ) on top of the pre-rift succession. Hammer for scale is $40 \mathrm{~cm}$ long. (D) Bioclastic deposits (Facies 1B) at the base of the syn-rift. Person for scale. (E) Detail of D. Bioclastic rudstone composed of dendritic coral fragments and molluscs. Pencil for scale is $15 \mathrm{~cm}$ long.

Figure 15. Facies 2 finely laminated mudstones with intercalations of tabular siltstones and very finegrained sandstones. Hammer for scale is $40 \mathrm{~cm}$ long.

This article is protected by copyright. All rights reserved. 
Figure 16. Unit 3 deposits. (A) Facies $3 \mathrm{~A}$ grain-supported conglomerates. (B) Facies $3 \mathrm{~A}$ and $3 \mathrm{C}$ beds downlapping onto Facies 2 (Unit 2) in the Log 3 area. (C) Unit 3 succession developed on top of Unit 2 in Log 5 area. Large-scale cross-set beds can be observed on the lower half of the deposit. (D) Facies 3A cross-sets deposited over Facies 4A (Unit 4) in the Log 2 area. Note the erosive nature of Unit 3 base. People for scale. For location of the sedimentary logs refer to Figs 4,10 and 12 . Coloured circles indicate the syn-rift units (U2: Unit 2, U3: Unit 3, U4: Unit 4).

Figure 17. Unit 4 deposits. (A) Unit 4 succession ( $65 \mathrm{~m}$ thick) developed on top of Unit 2 in the area between Logs 10 and 11 . The base of Unit 4 is defined by a regressive surface of marine erosion while its top is represented by a marine flooding surface succeeded by Unit 5 deposits. (B) View of the base of Unit 4, composed in this case of Facies 4A. Person for scale. (C) Typical Ophiomorpha burrows in Facies 4A. Compass for scale is $10 \mathrm{~cm}$ long. (D) Facies $4 B$ channel cutting into underlying Facies 4A deposits. (E) Facies 4B geometry is composed of lenses and wedges defined by the erosive nature of the channels. For location of the sedimentary logs refer to Figs 4 and 11 . Coloured circles indicate the syn-rift units (U2: Unit 2, U4: Unit 4, U5: Unit 5).

Figure 18. Evolution of the sedimentary environments at the EQFB hangingwall dipslope (CF: Coastal Fault Belt; EF: Eastern Boundary Fault Belt). Representation of the Eastern Boundary Fault Belt is schematic and only for illustrative purposes. Models and cross sections are not to scale. Strike and dip section locations in the models are indicated by thick black lines. (A) First phase of hangingwall tilting and deposition, earliest syn-rift, Unit 1. The marine transgression followed the direction of fault propagation along the Coastal Fault Belt (B) Second phase of hangingwall tilting, deposition of Unit 2. (C) Deposition of units 3 and 4 after tilting 2.

This article is protected by copyright. All rights reserved. 
(A)

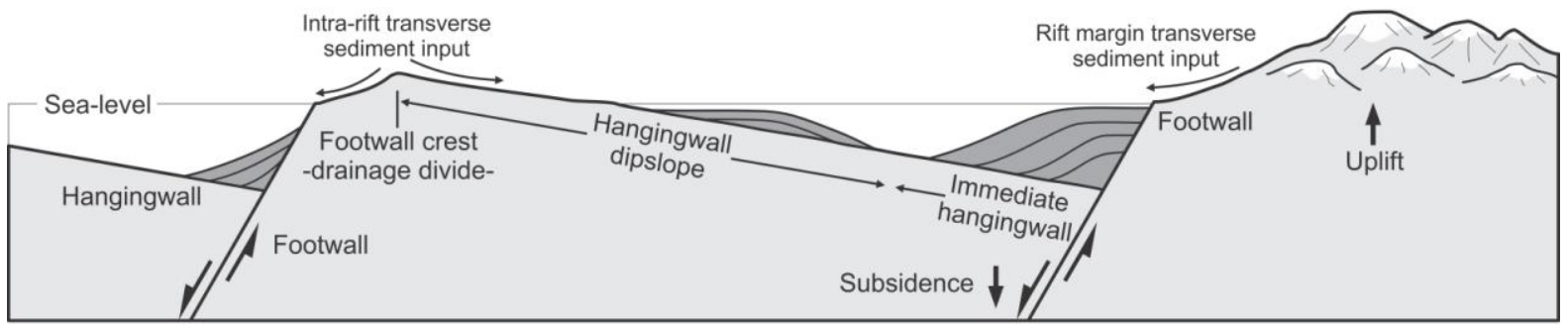

\section{(B)}

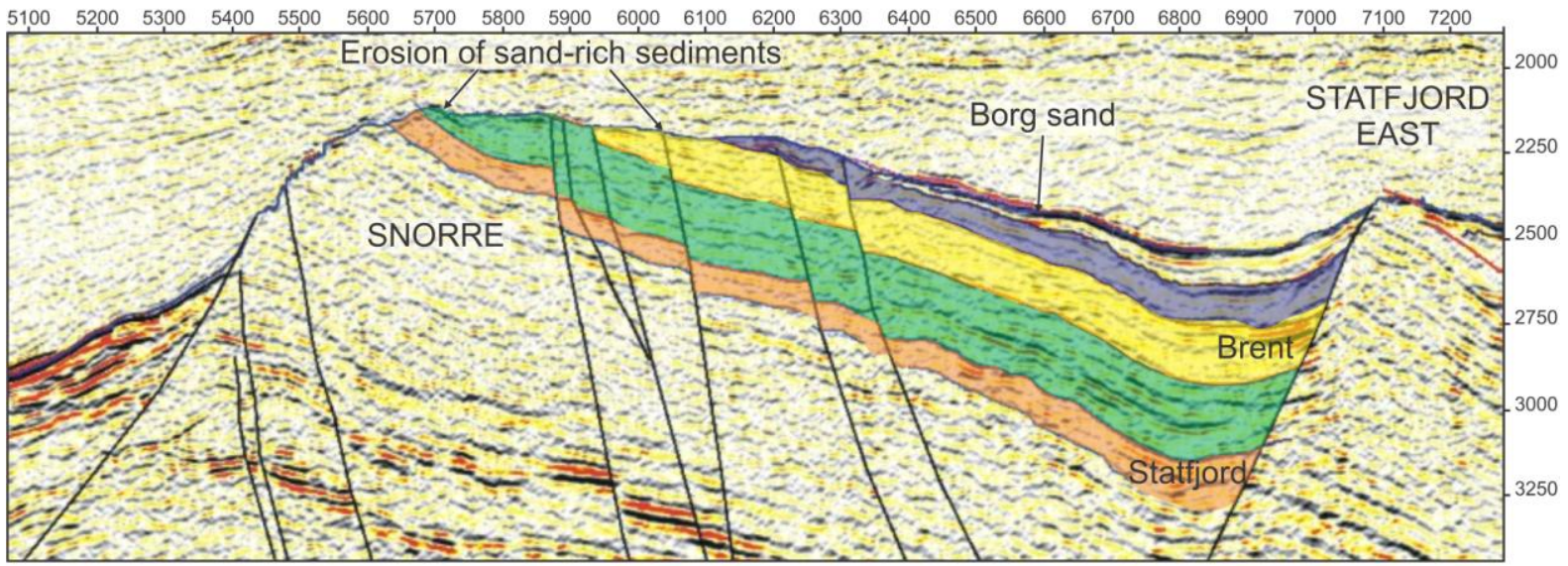

(C)

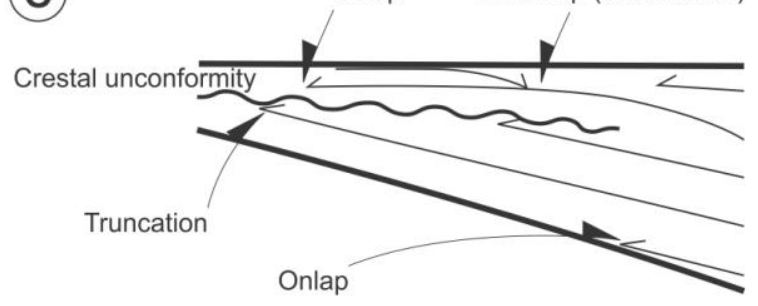

D Retreating hangingwall depositional systems

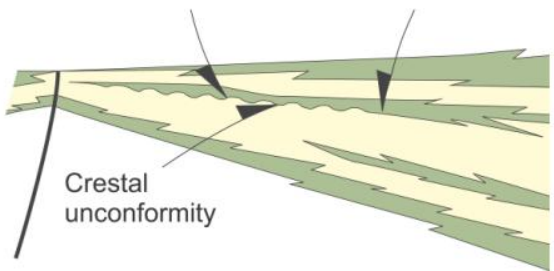

This article is protected by copyright. All rights reserved. 


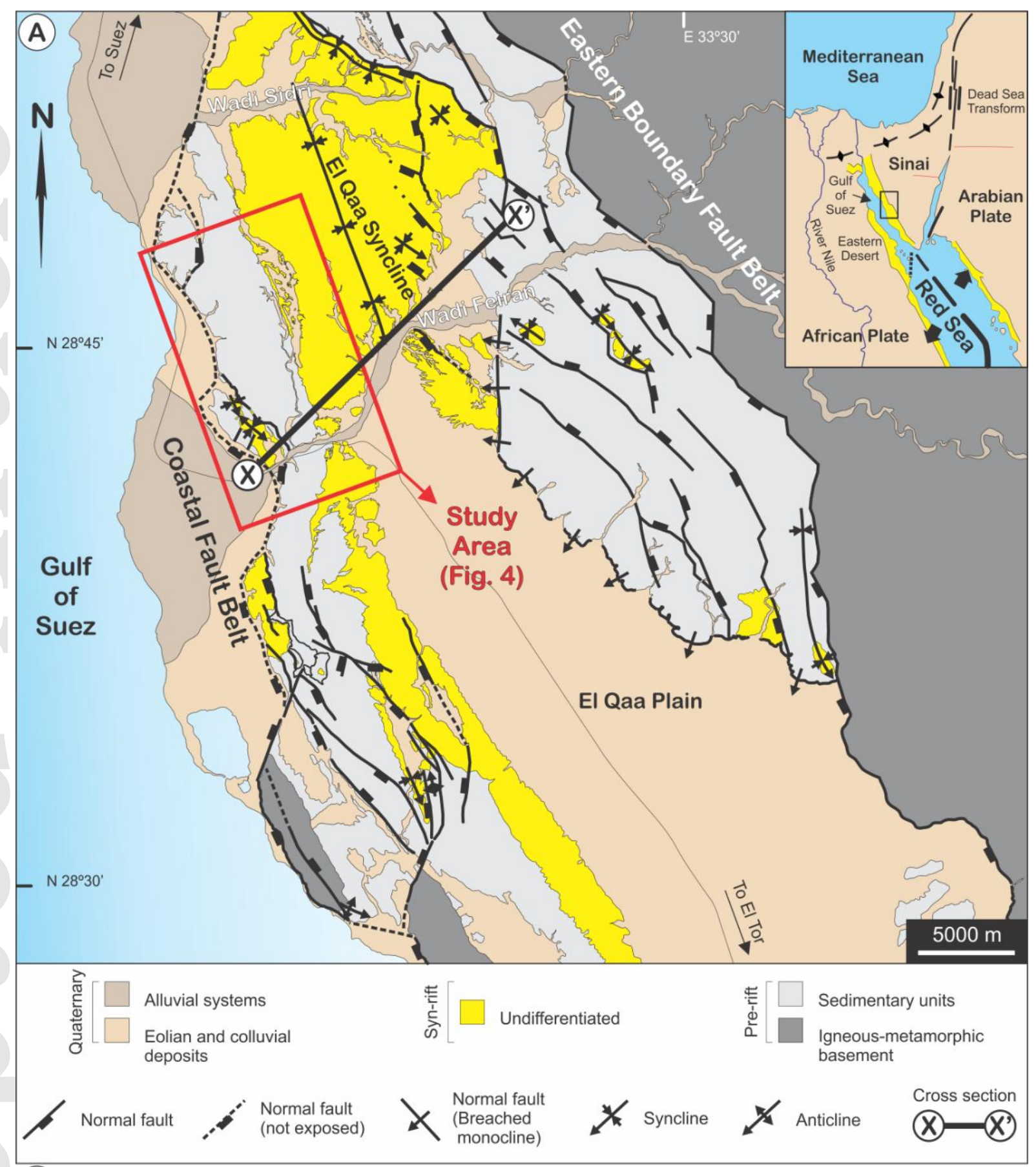

(B)

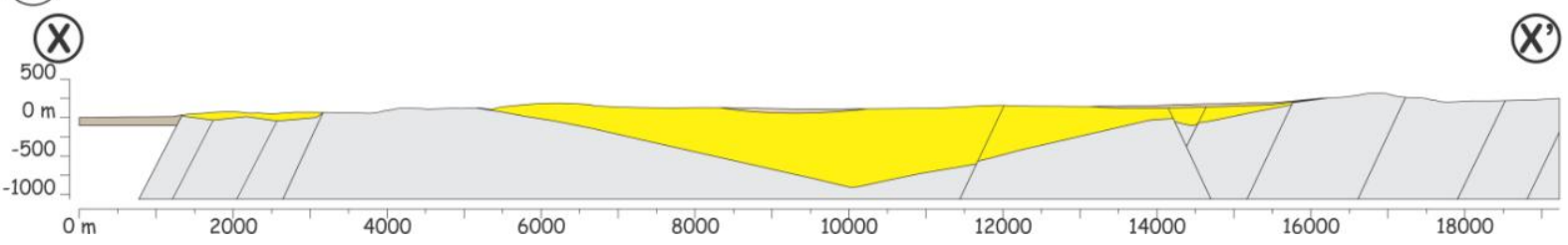

This article is protected by copyright. All rights reserved. 


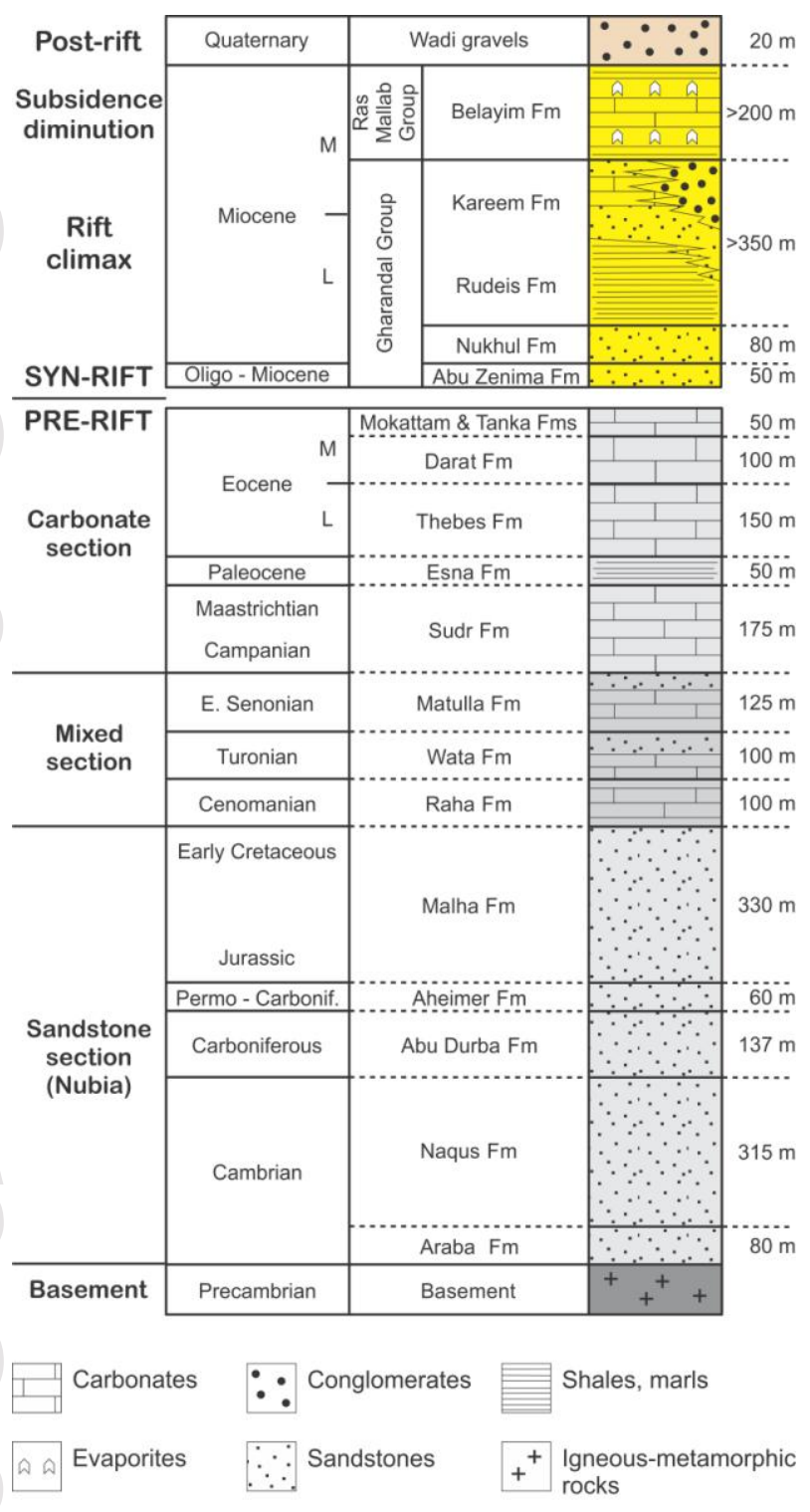

This article is protected by copyright. All rights reserved. 


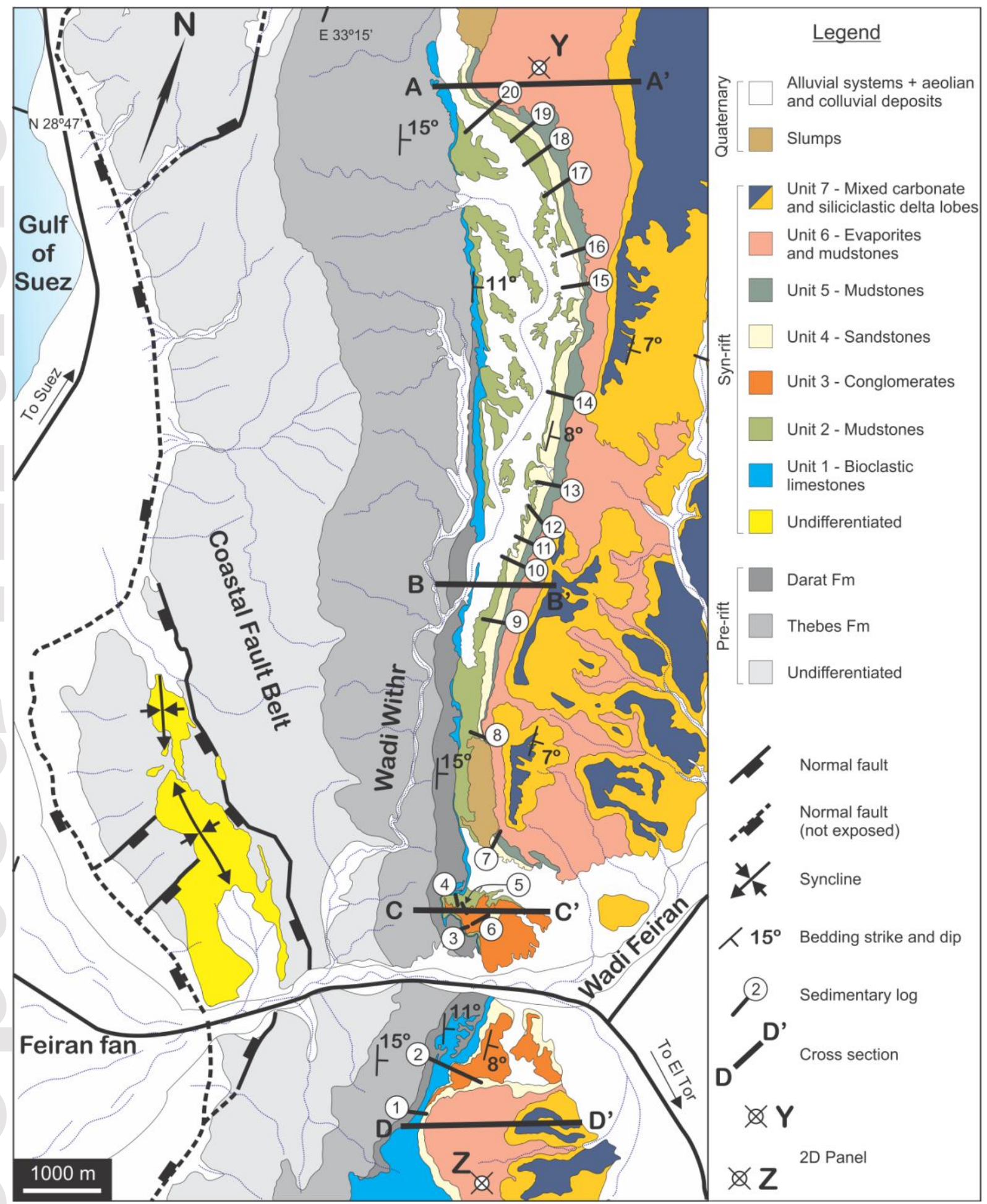

This article is protected by copyright. All rights reserved. 


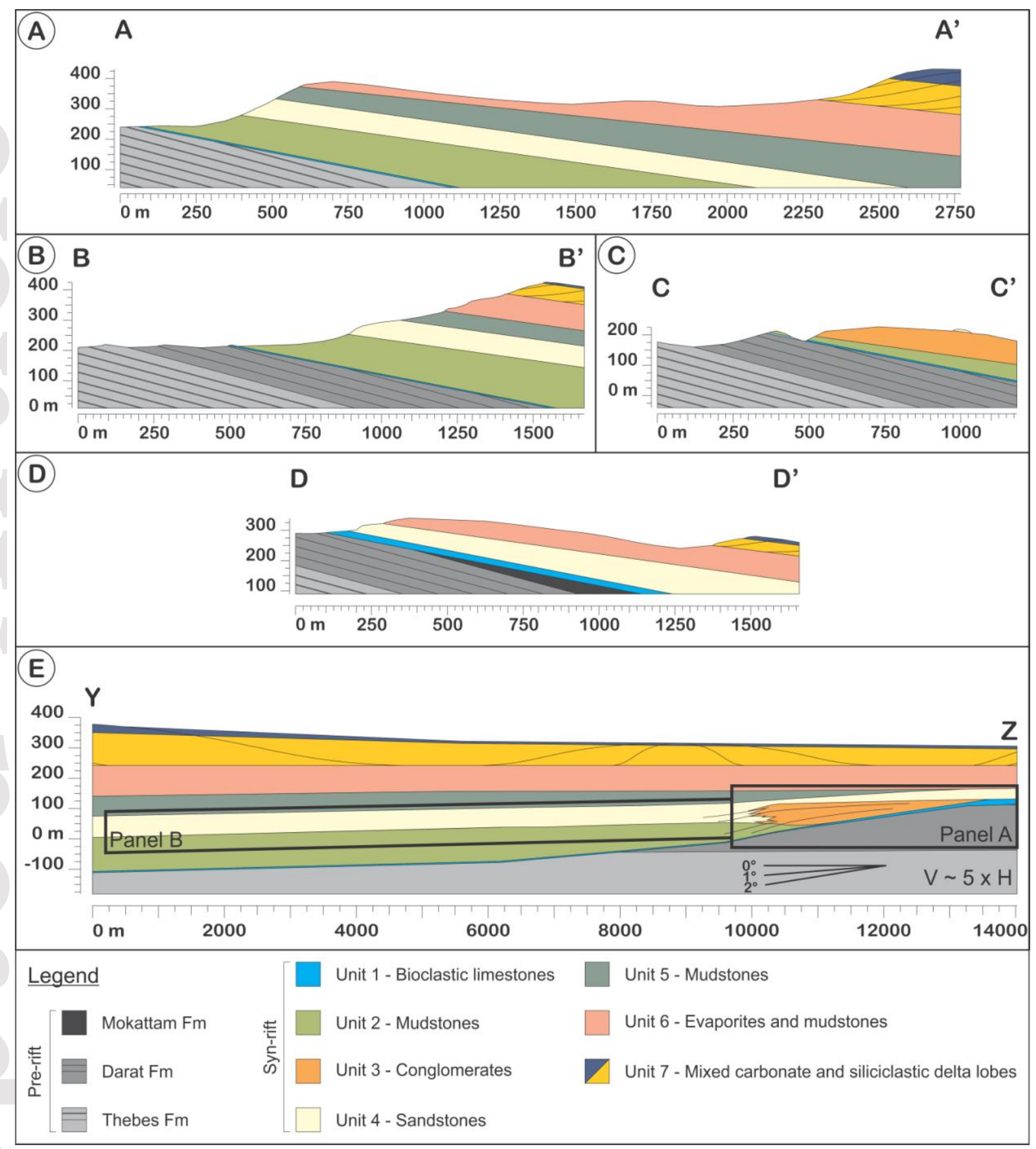

This article is protected by copyright. All rights reserved. 


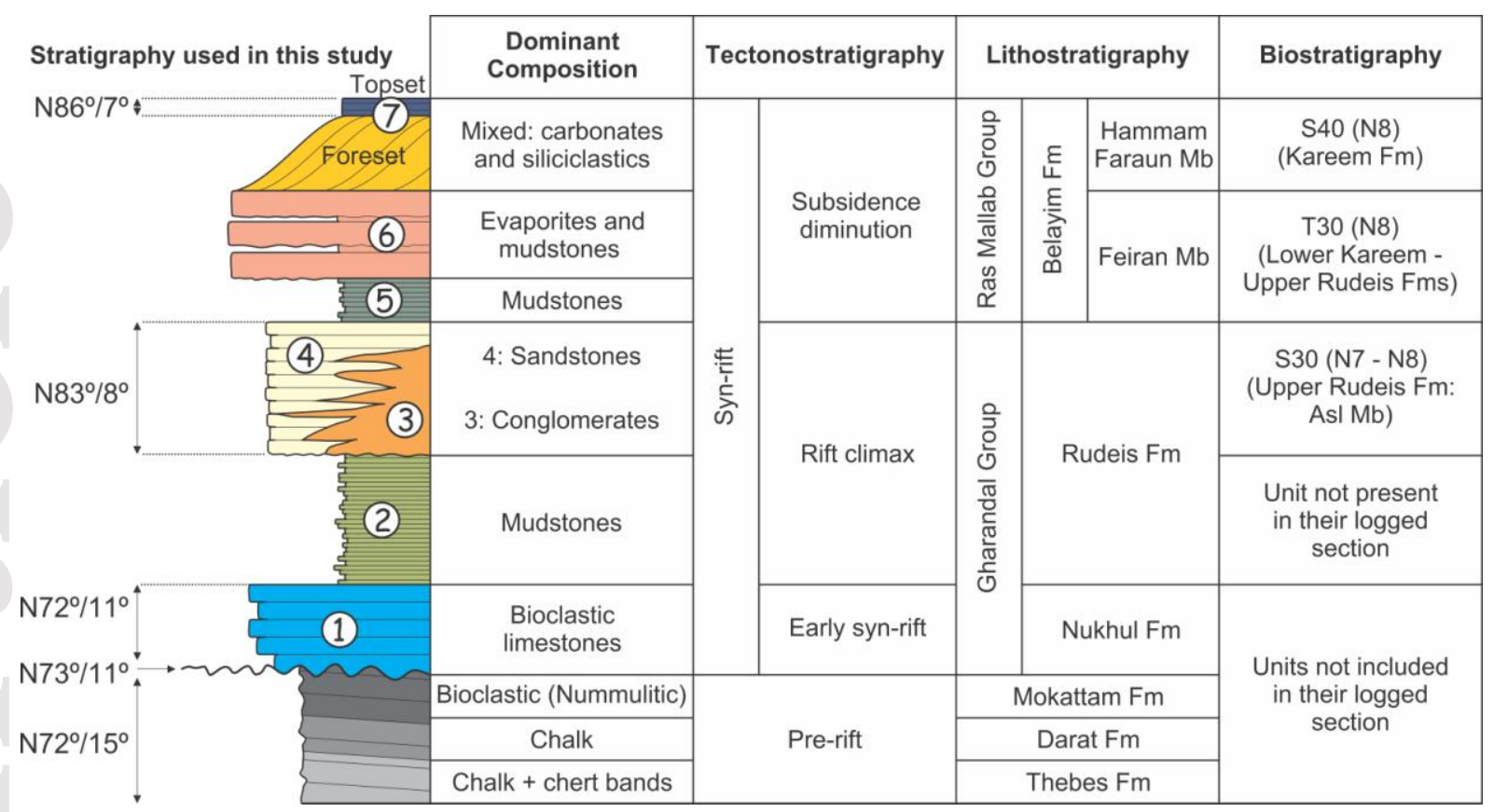
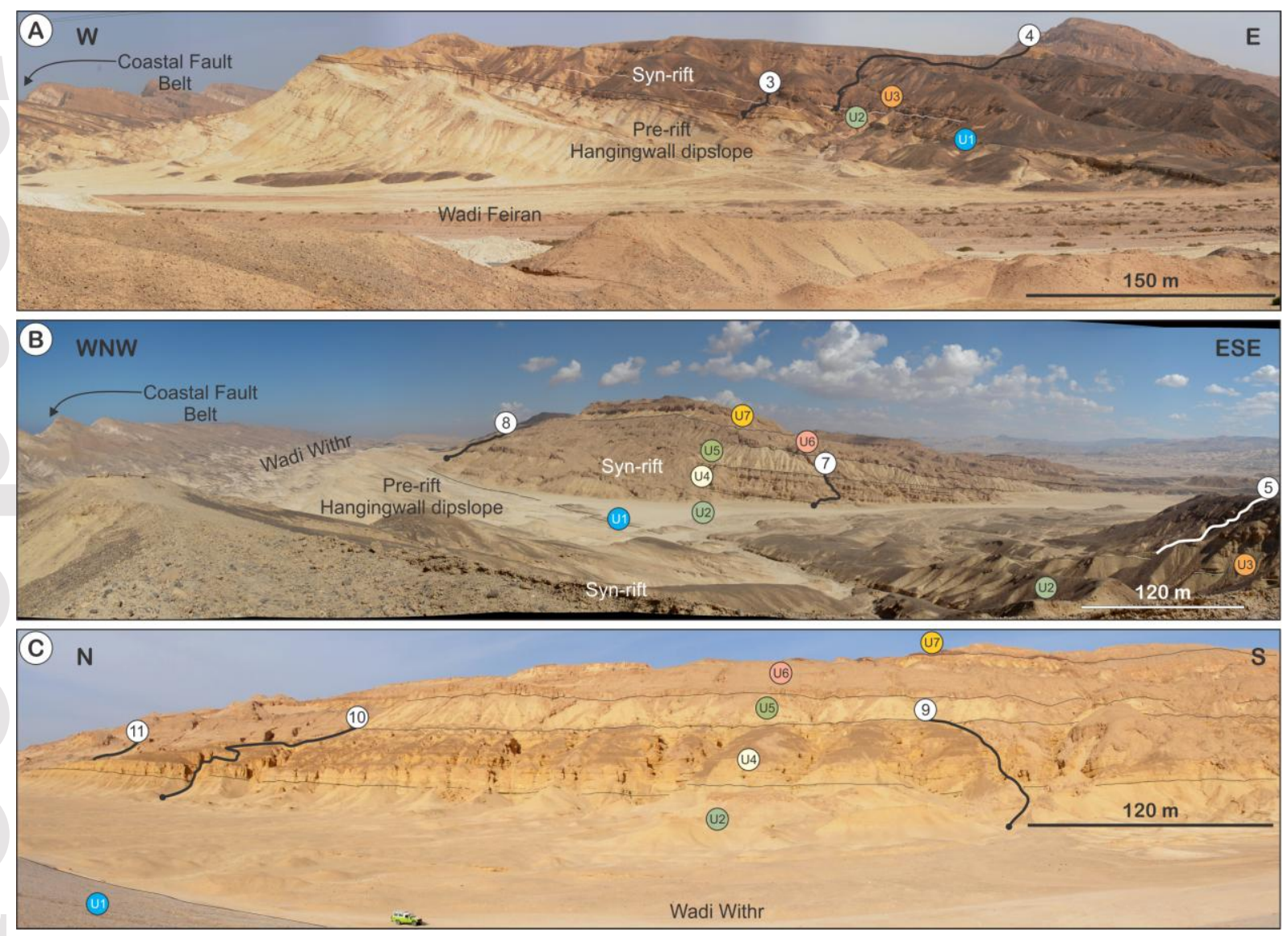

This article is protected by copyright. All rights reserved. 

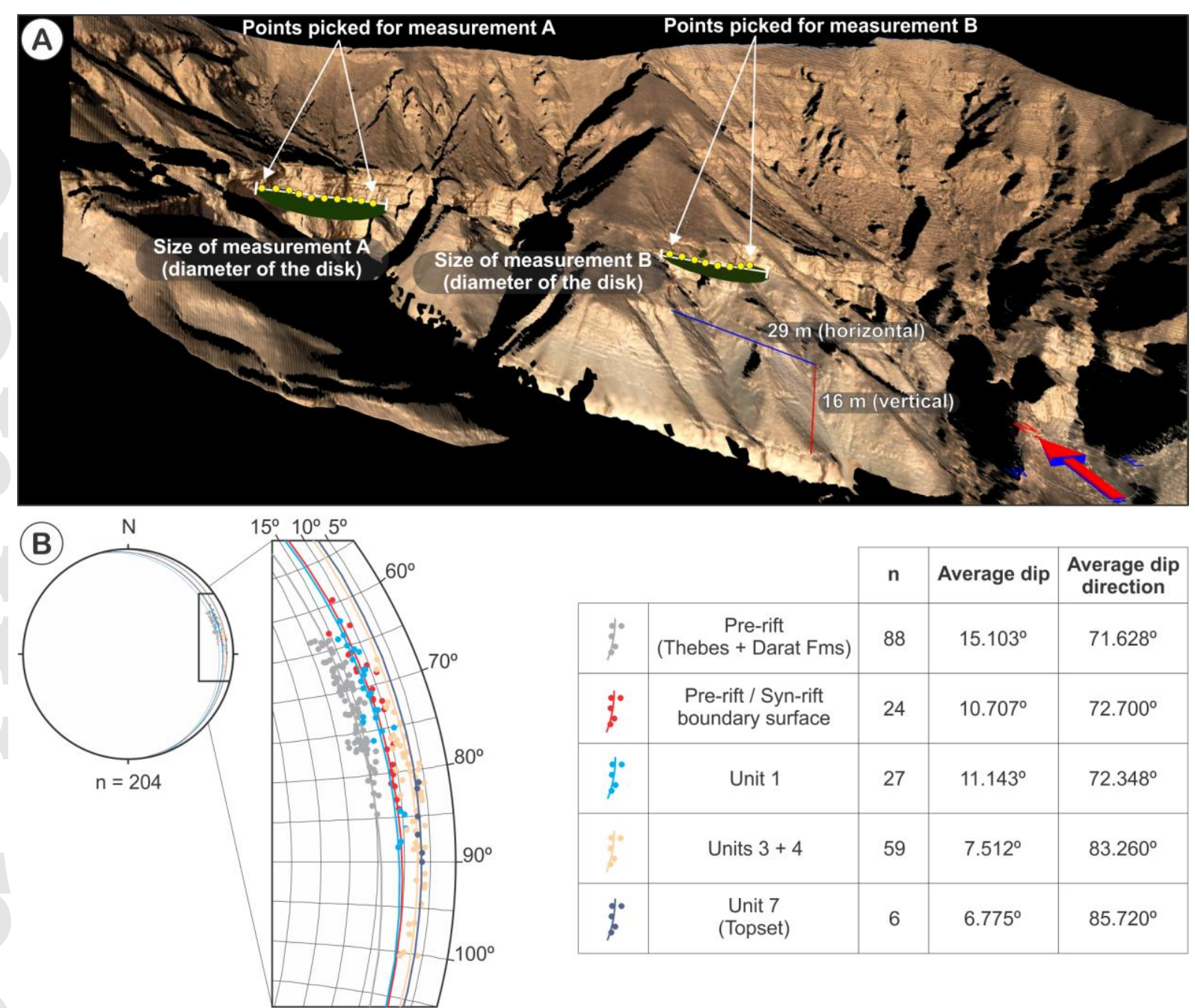

\begin{tabular}{|c|c|c|c|c|}
\hline & & $\mathrm{n}$ & Average dip & $\begin{array}{l}\text { Average dip } \\
\text { direction }\end{array}$ \\
\hline$\%$ & $\begin{array}{c}\text { Pre-rift } \\
\text { (Thebes + Darat Fms) }\end{array}$ & 88 & $15.103^{\circ}$ & $71.628^{\circ}$ \\
\hline$\%$ & $\begin{array}{l}\text { Pre-rift / Syn-rift } \\
\text { boundary surface }\end{array}$ & 24 & $10.707^{\circ}$ & $72.700^{\circ}$ \\
\hline के & Unit 1 & 27 & $11.143^{\circ}$ & $72.348^{\circ}$ \\
\hline$\%$ & Units $3+4$ & 59 & $7.512^{\circ}$ & $83.260^{\circ}$ \\
\hline q & $\begin{array}{l}\text { Unit } 7 \\
\text { (Topset) }\end{array}$ & 6 & $6.775^{\circ}$ & $85.720^{\circ}$ \\
\hline
\end{tabular}

Frequency (\%)
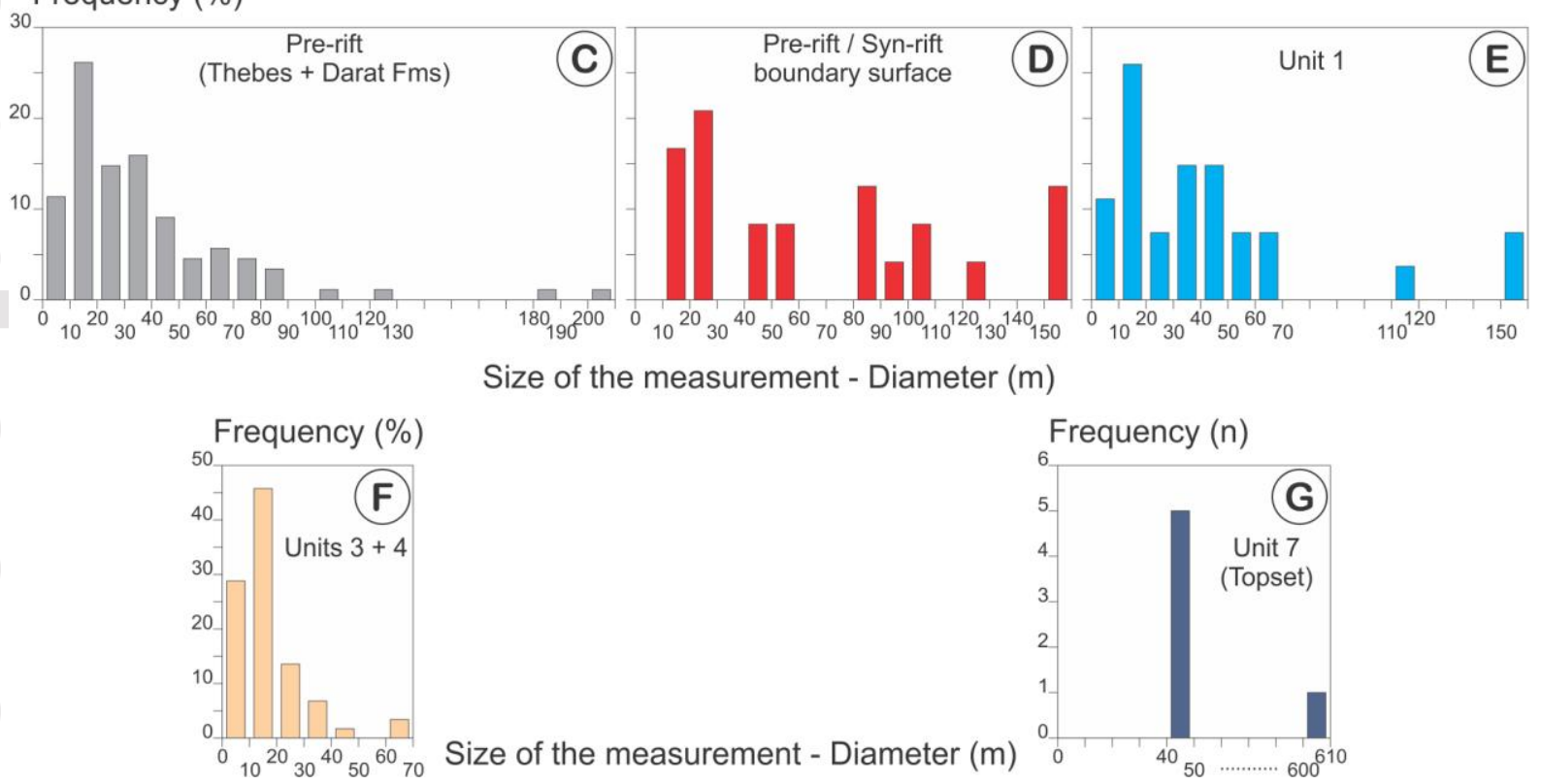

This article is protected by copyright. All rights reserved. 


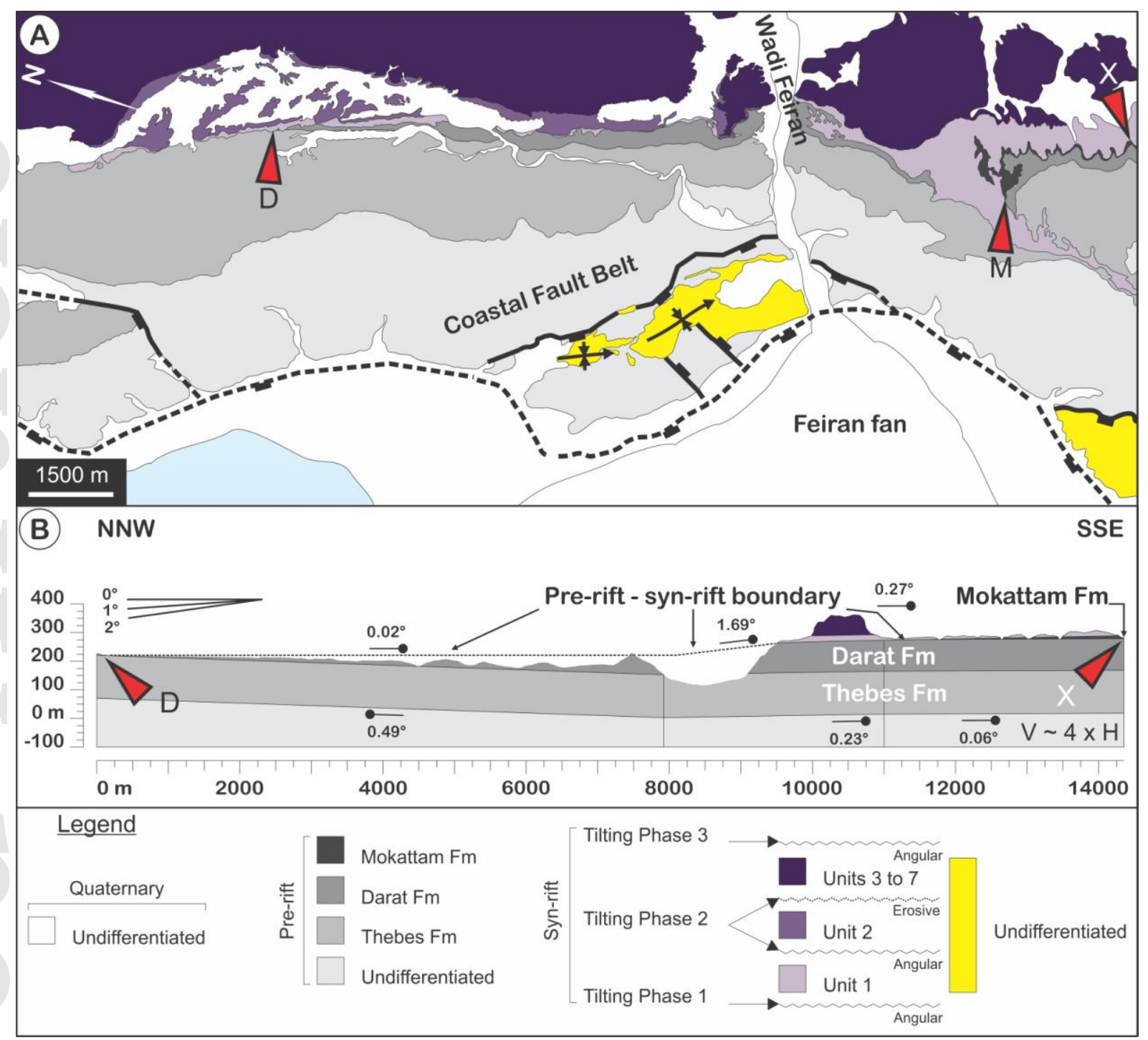

This article is protected by copyright. All rights reserved. 

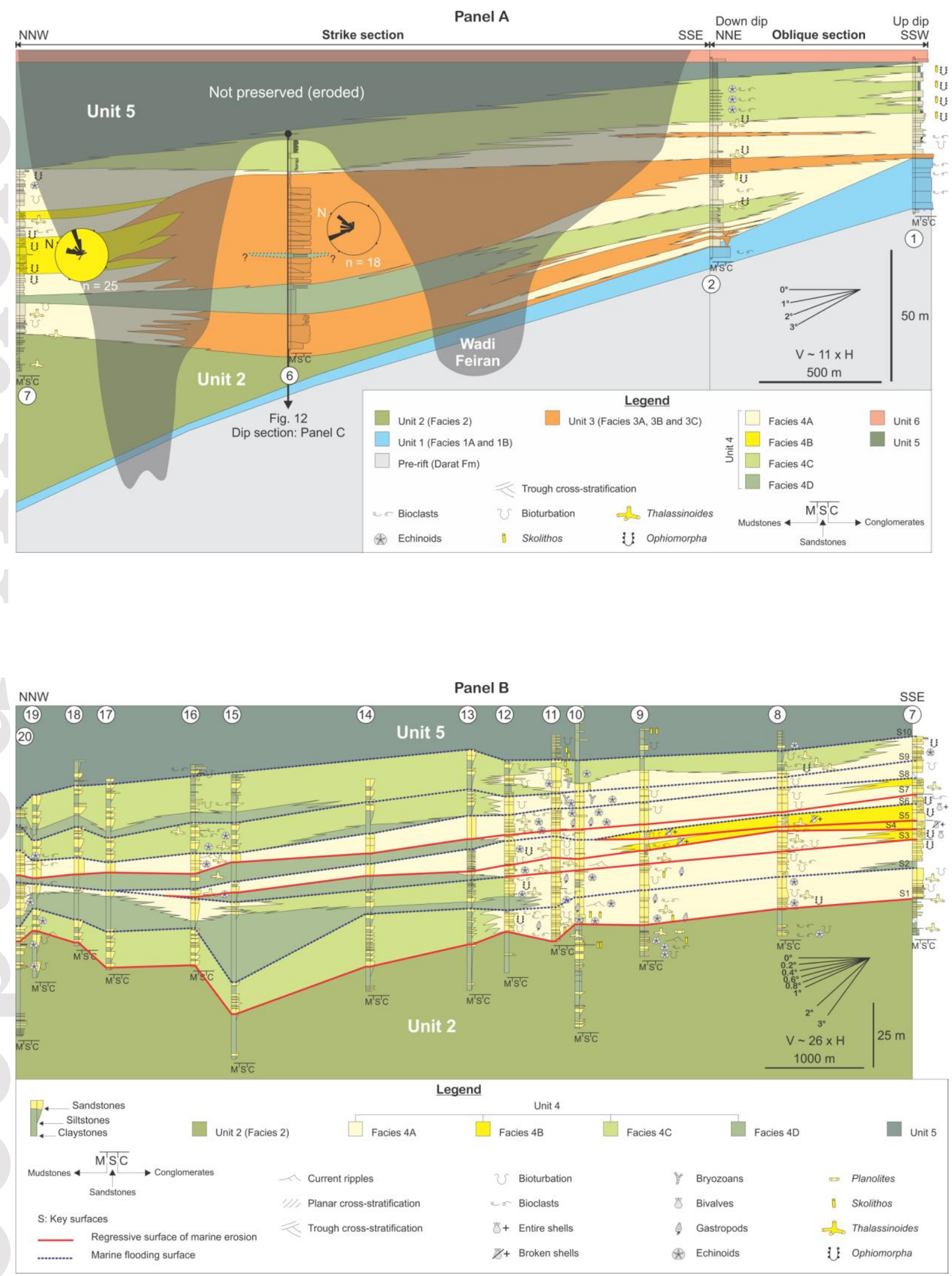

This article is protected by copyright. All rights reserved. 

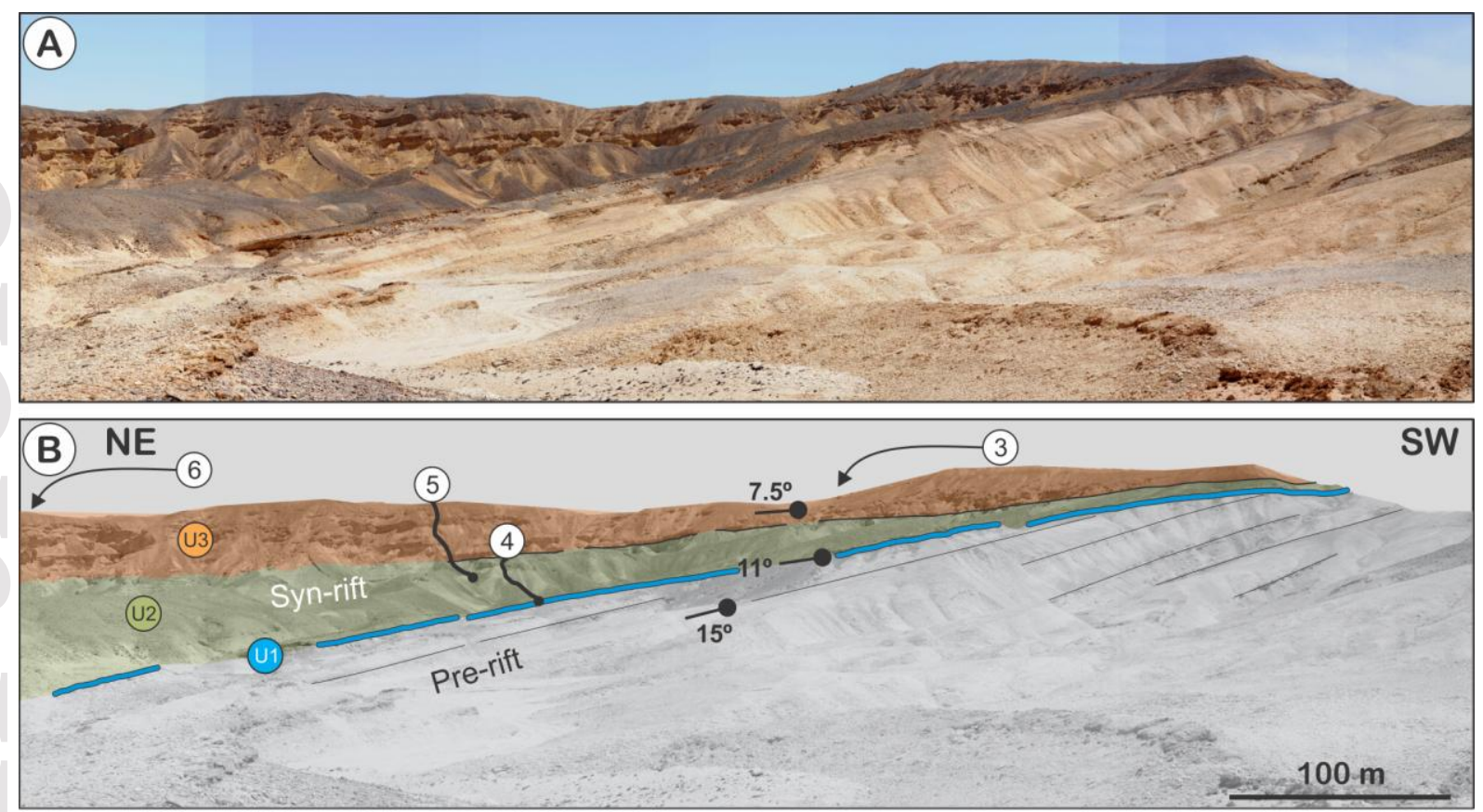

(C)

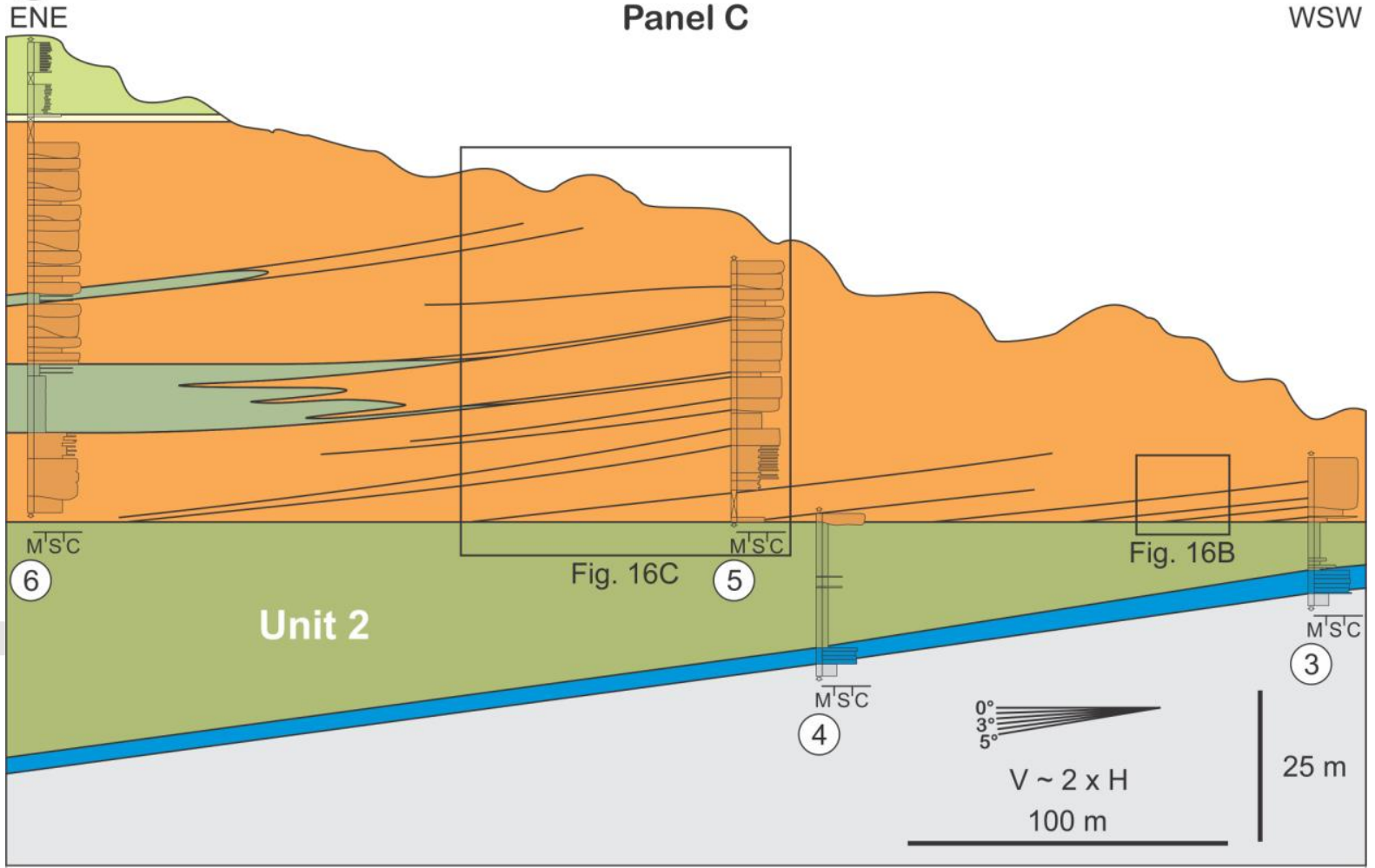

\section{Legend}

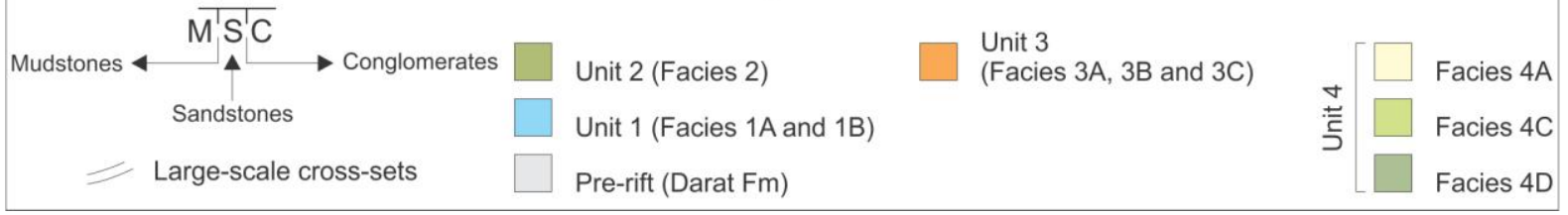

This article is protected by copyright. All rights reserved. 
(A)

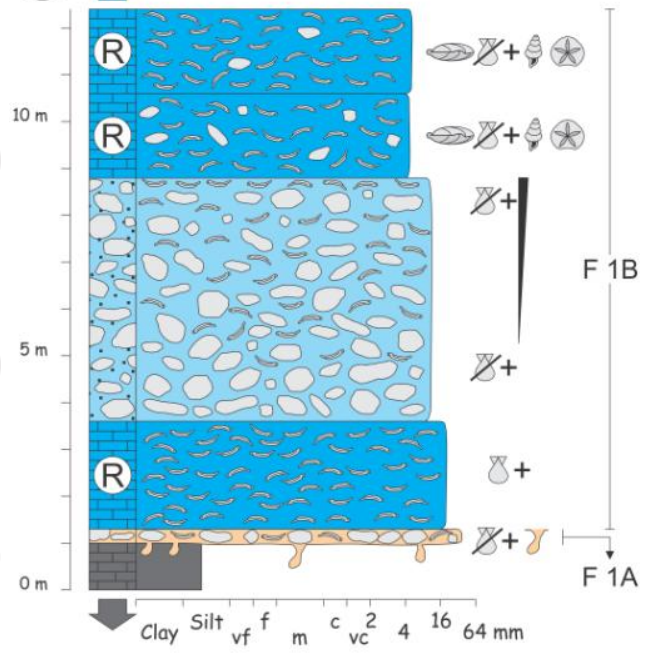

(D)

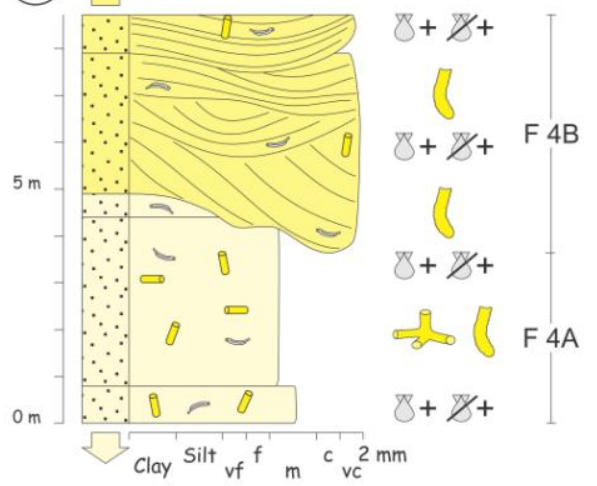

(B)

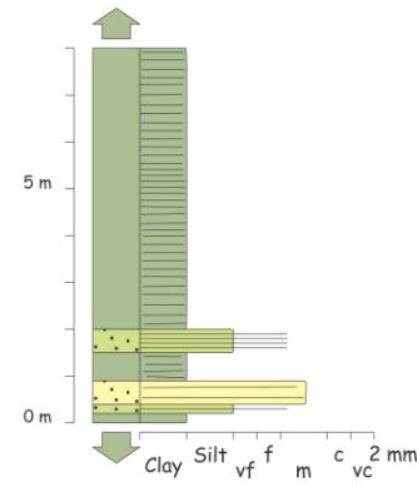

(C)

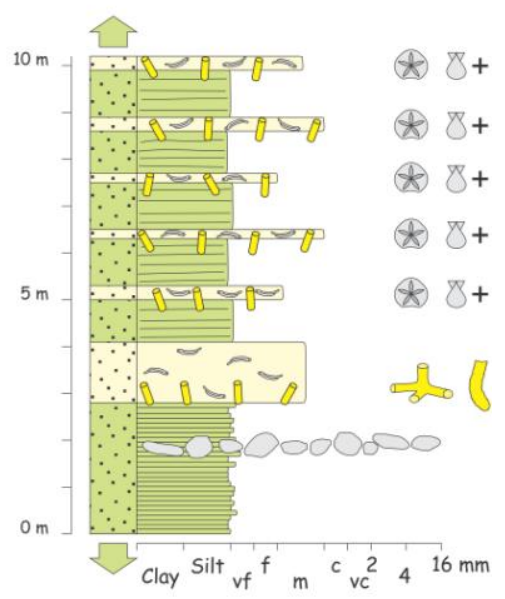

(E)

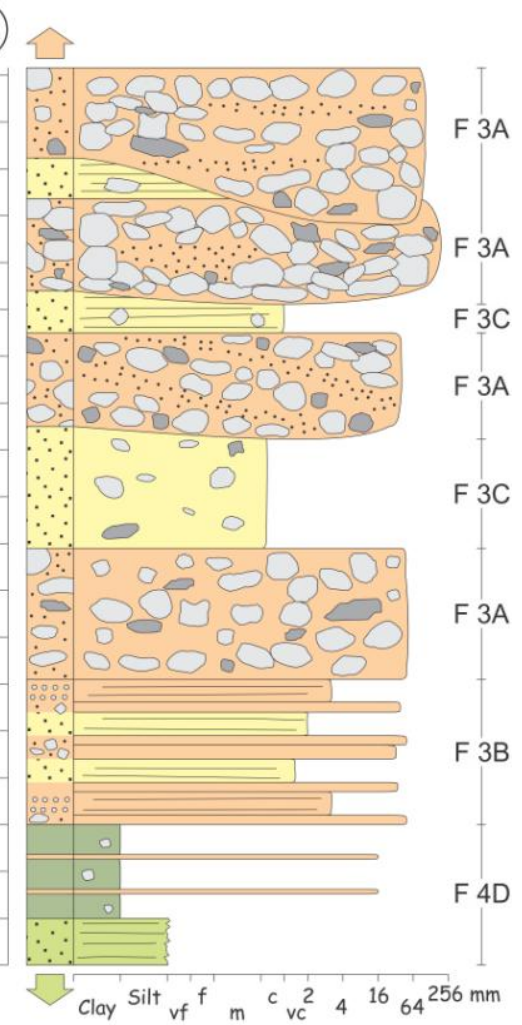

G. Gastropods

Æ Echinoids

Brachiopods

f Undifferentiated

trace fossils

مुo Thalassinoides

(7) Ophiomorpha

$\gamma$ Gastrochaenolites 

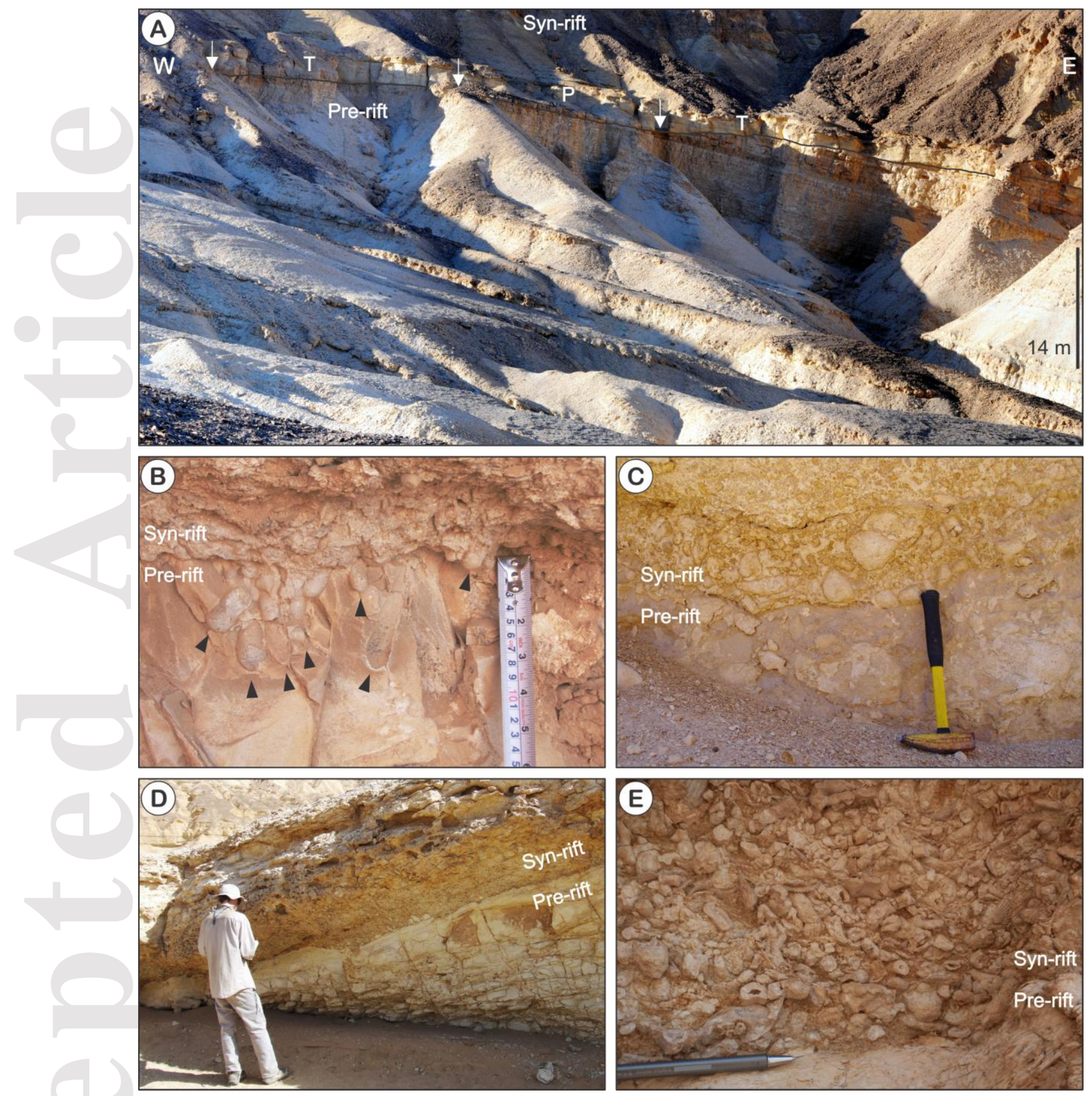

This article is protected by copyright. All rights reserved. 

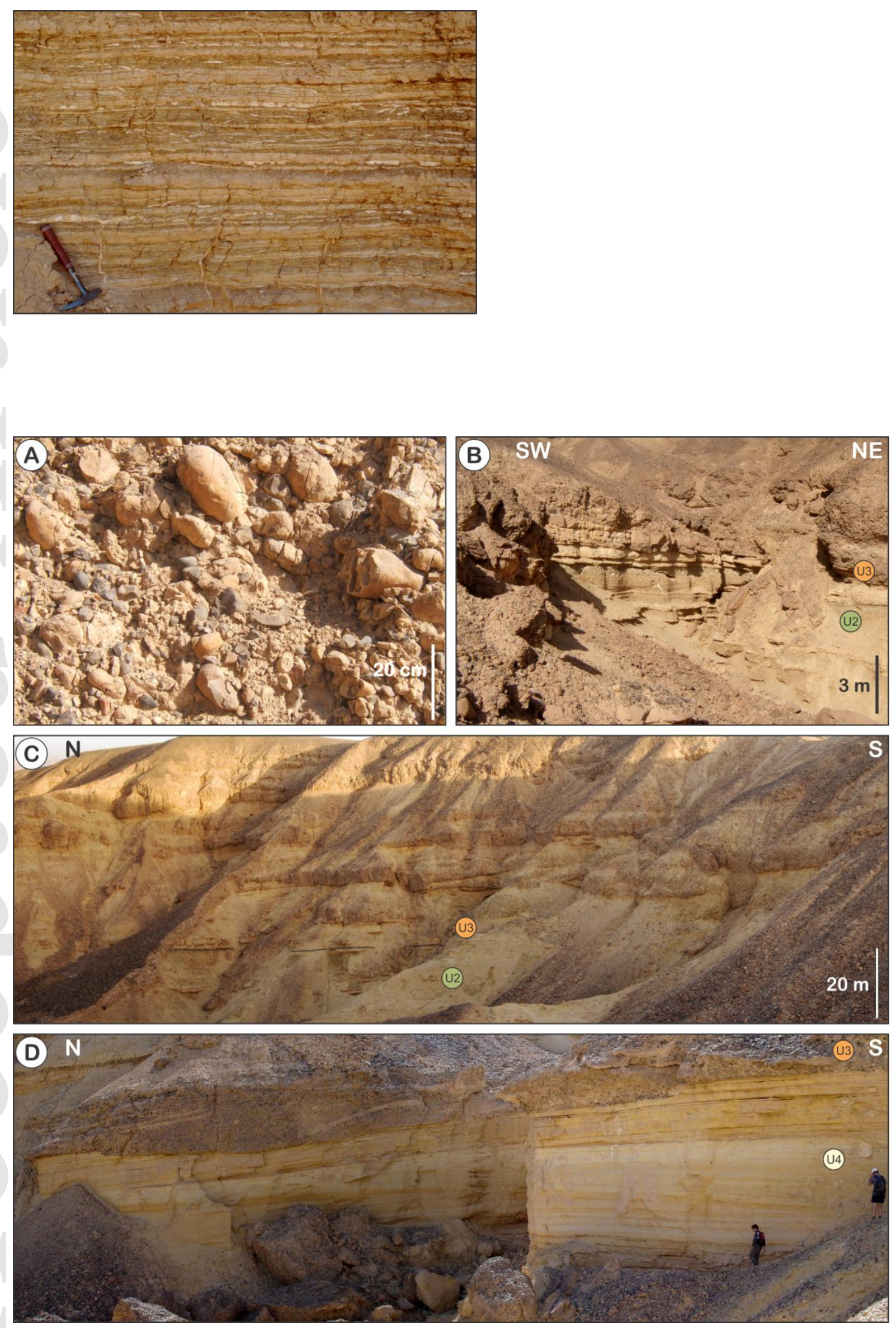

This article is protected by copyright. All rights reserved. 

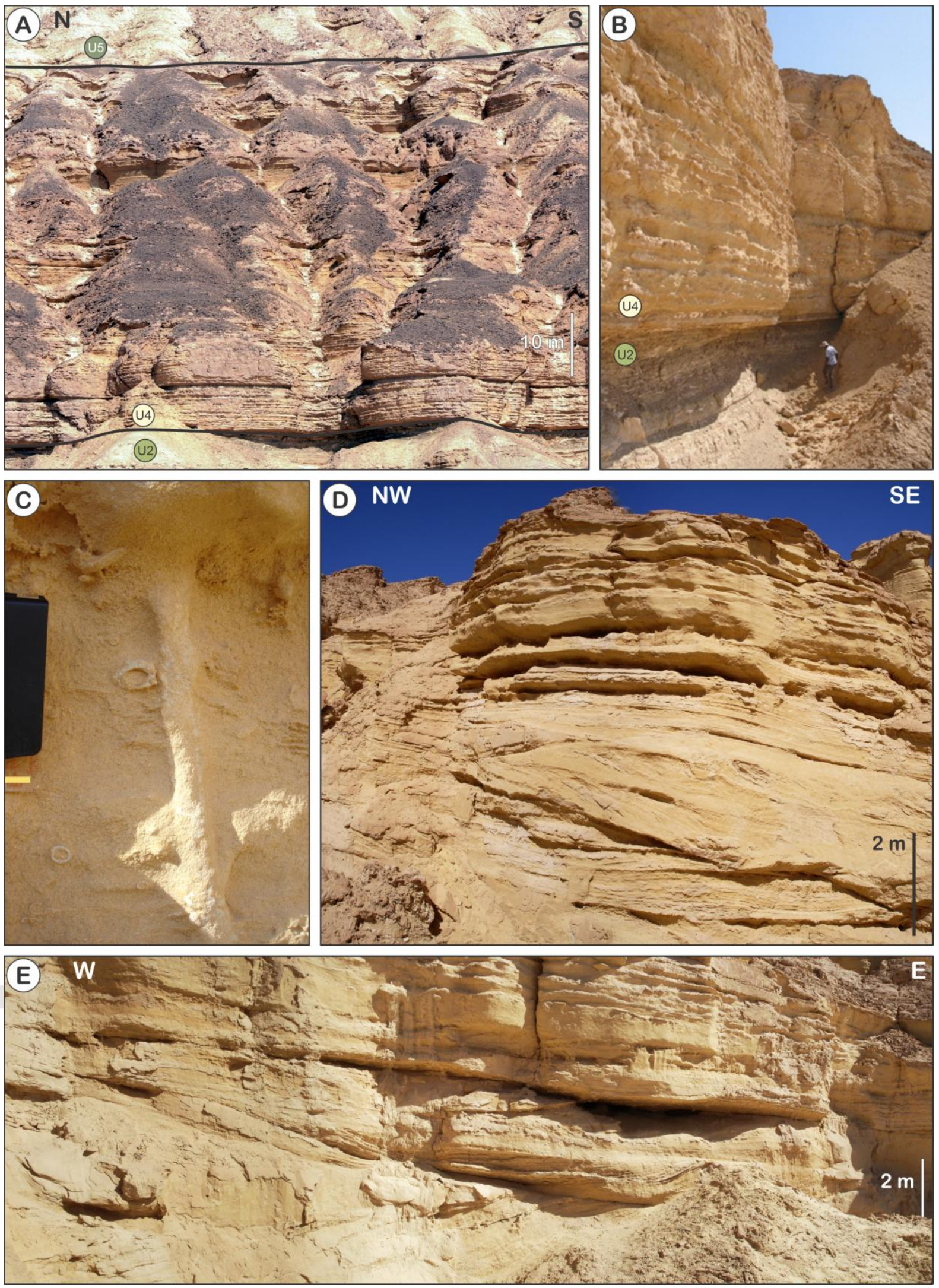

This article is protected by copyright. All rights reserved. 

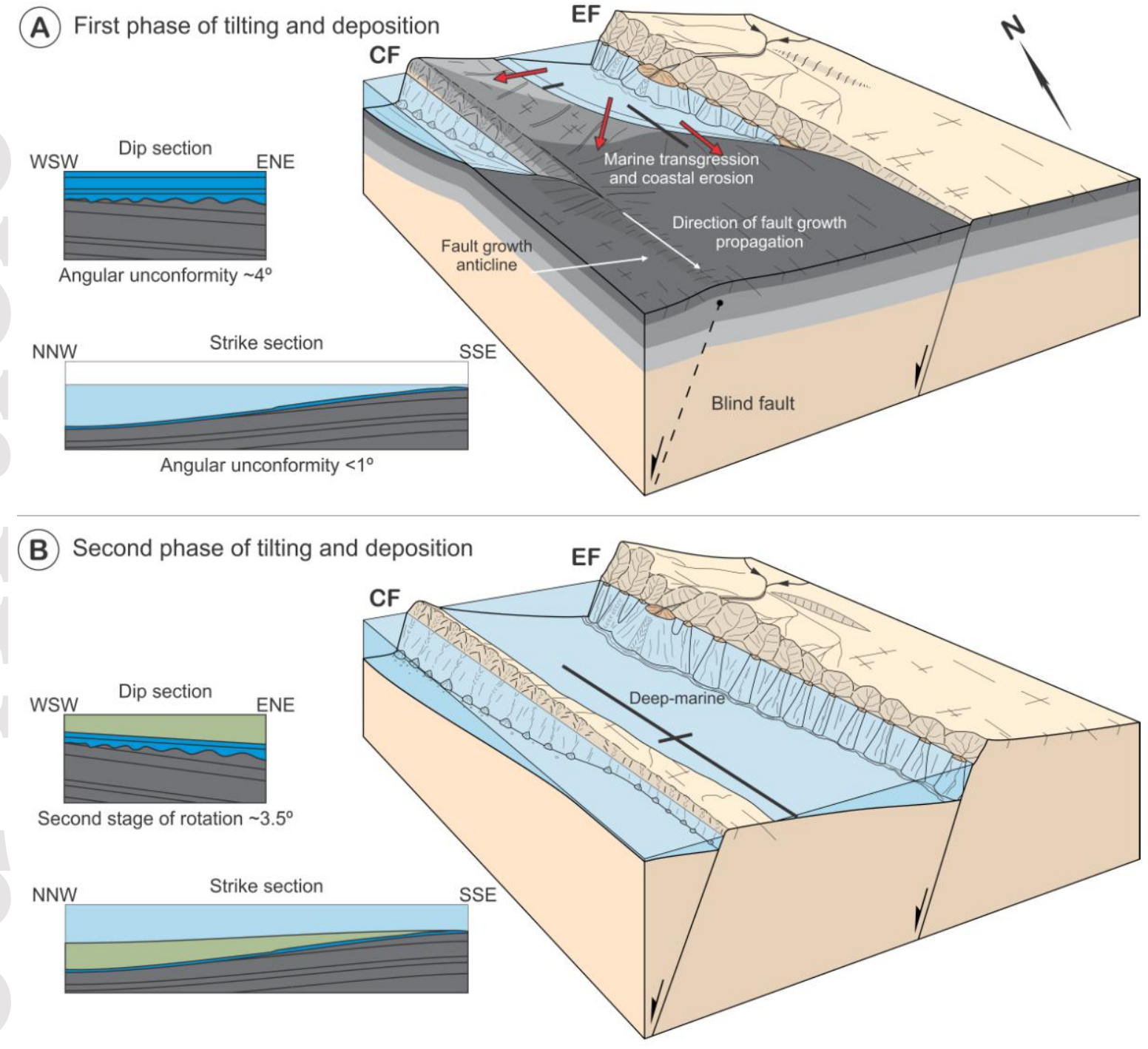

(C) Deposition after tilting 2
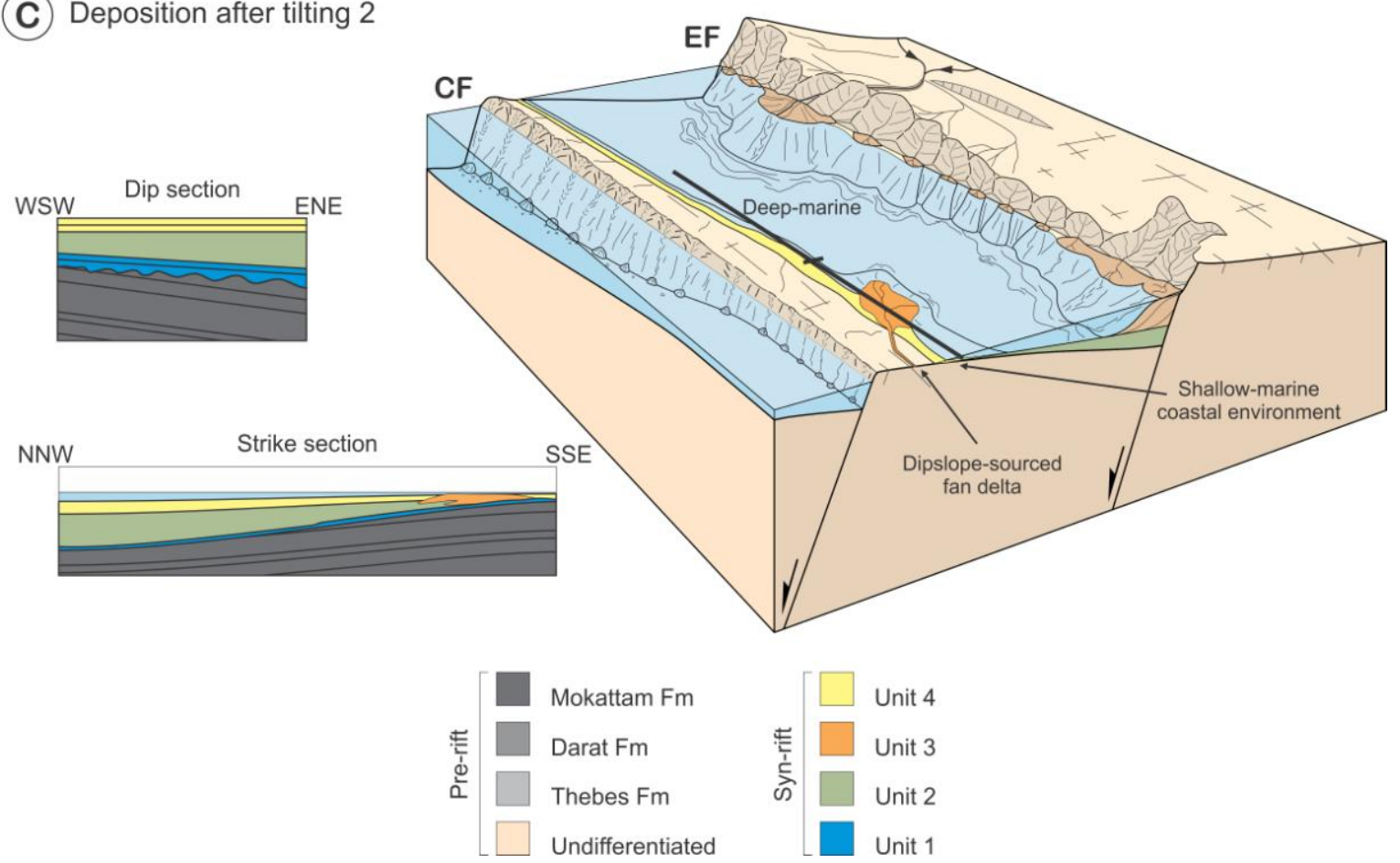

This article is protected by copyright. All rights reserved. 